Mr Srđa Primus, dipl. inž.

\section{ELEMENTI INTEGRALNOG TEHNIČKOG OBEZBEDENJA I NJIHOVE KARAKTERISTIKE}

Rezime:

U ovom radu opisani su elementi i karakteristike integralnog tehničkog obezbeđenja (ITOb-a) o kojima treba voditi računa prilikom nabavke gotovih sistema naoružanja $i$ vojne opreme (NVO) na tržištu. Zbog toga su prvo navedeni svi elementi, date njihove definicije $i$ prikazana medusobna povezanost $i$ uslovljenost $u$ obezbeđenju odgovarajućeg stepena radne $i$ borbene gotovosti. Uz svaku karakteristiku dato je obrazloženje iz kojeg se može sagledati zbog čega je važno blagovremeno saznati $i$ precizirati njenu st!arnu vrednost.

Ključne reči: integralno tehničko obezbeđenje (ITOb), pogodnost za održavanje, pouzdanost, radna gotovost, sistern održavanja.

\title{
ELEMENTS OF INTEGRAL TECHNICAL SUPPORT AND THEIR CHARACTERISTICS
}

\section{Summary:}

In the article are described elements and characteristics of integral technical support that have to be kept in mind when complete armament and military equipment are purchased. Therefore are first listed all these elements, their definitions are given, and their interconnection and interrelationship in securing the wanted level of their working and combat readiness are reviewed. With each of these characteristics is given an explanation from which can be seen the necessity of the timely grasping and precisely establishing its real value.

Key words: integral technical support, viability of integral technical support, reliability of integral technical support, readiness for function of integral technical support, system of maintaining the integral technical support.

\section{Uvod}

Sve karakteristike nekog sredstva ili sistema mogu se svrstati u tri velike grupe.

U prvu grupu spadaju karakteristike koje definišu funkcionalnost, odnosno sve ono zbog čega se sredstvo nabavlja. One se obično navode u prospektima i drugoj literaturi sredstava ili sistema.
Drugu grupu čine karakteristike koje iskazuju koliko konstrukciona rešenja proizvoda utiču na zaštitu čoveka i okoline. U njih spadaju već ranije poznate karakteristike zaštite na radu, $\mathbf{i}$ druge koje navode stepen ugroženosti, ali i zaštite ljudi i okoline. Ova grupa karakteristika uskoro ce biti obrađena $\mathrm{u}$ internacionalnim standardima ekološke zaštite, koji ce propisati veličine ovih karakteristika koje moraju imati proizvodi na međunarodnom tržištu. 
Poslednjom grupom karakteristika obuhvaćene su one koje omogućavaju sagledavanje i određivanje očekivane vrednosti radne gotovosti (ili raspoloživosti), za koju su već dosta dugo zainteresovani veliki korisnici složenih tehničkih sistema (vojska, elektroprivreda, železnica, velike vazduhoplovne kompanije, pošta i slično). Pri tome se pod radnom gotovošću podrazumeva verovatnoća da će proizvod, $u$ trenutku potrebe, biti spreman i sposoban za rad, (iskazuje se i meri procentualnim odnosom između broja trenutno ispravnih i broja ukupno nabavljenih sredstava).

Ova poslednja grupa dalje se deli na više skupova međusobno srodnih karakteristika koje određuju osobine sredstva, kao što su pouzdanost, pogodnost za održavanje i prilagođenost mo. gućnostima korisnika, kao i osobine elemenata podrške koje isporučuje proizvođač. Pod elementima podrške podrazumeva se sve ono što isporučuje proizvođač radi obezbeđenja besprekornog rada i održavanja nabavljenog sredstva ili sistema.

Elementi ITOb-a su skupovi karakteristika nabavljenog proizvoda i elemenata njihove podrške, odnosno skupovi koji omogućavaju procenu očekivanog stepena ispravnosti (radne i borbene gotovosti) sredstva ili sistema, kao i sagledavanje problema eksploatacije i održavanja ispravnosti.

\section{Elementi integralnog tehničkog obezbeđenja}

U elemente ITOb-a spadaju:

- pouzdanost,

- pogodnost za održavanje,

- prilagođenost za korišćenje standardizovanih vrsta goriva, maziva, municije ili izvora električne energije,
- prilagođenost proizvoda mogućnostima korisnika (uklapanje u postojeći sistem eksploatacije i održavanja),

- dokumentacija za održavanje,

- individualni i grupni kompleti rezervnih delova, alata $i$ pribora (RAP),

- oprema za održavanje i ispitna oprema,

- rezervni delovi za održavanje,

- početna obuka kadrova predviđenih za održavanje ili nastavnika koji bi osposobljavali kadrove za održavanje.

Pouzdanost je sposobnost proizvoda da obavlja zahtevanu funkciju $u$ konkretnim i definisanim uslovima, načinu eksploatacije i održavanja. Izražava se verovatnoćom da će sredstvo biti funkcionalno ispravno $u$ zadatom periodu.

Pogodnost za održavanje je prilagođenost proizvoda za jednostavno i brzo preventivno i korektivno održavanje koje bi realizovali za to osposobljeni kadrovi, uz korišćenje propisane remontne opreme i dokumentacije. Iskazuje se vrednostima karakteristika kao što su: pogodnost za opravku što bliže mestu korišćenja, srednje vreme realizacije radnji preventivnog održavanja (koje se, prema preporukama proizvođača, moraju obaviti posle određenog vremenskog perioda) i srednje ili maksimalno vreme opravki (posebno za nivoe lakog, srednjeg i generalnog remonta).

Treba napomenuti da, pored navedenih karakteristika postoje i kvalitativne karakteristike pogodnosti za održavanje. One predstavljaju skup zahteva za projektovanje $i$ razvoj konstrukcionog rešenja koje je posebno pogodno za održavanje (npr. dobra pristupačnost, jednostavnost montaže, demonta- 
že i zamene delova, jednostavnost podešavanja, mogućnost automatske indikacije sklopa koji je izazvao otkaz, i sl.). Njihovim zadovoljenjem ostvaruju se željene vrednosti navedenih karakteristika.

Uklapanje proizvoda u organizacijsko-formacijska rešenja i uslove postojećeg sistema održavanja je stepen usaglašenosti uslova i načina održavanja koje preporučuje proizvođač (uslovljeni su konstrukcionim rešenjem ponuđenog proizvoda) sa uslovima i načinom održavanja koje može da obezbedi kupac. Ako postoje velike razlike između preporučenih i mogućih uslova i načina održavanja, sigurno je da ne može odgovarati ni dokumentacija u kojoj je proizvođač propisao razrađene postupke održavanja, niti mogu biti realne deklarisane vrednosti pouzdanosti i pogodnosti za održavanje (date su pod pretpostavkom da se eksploatacija i održavanje vrše u uslovima i na način koje je proizvođač predvideo).

Određivanje stepena usaglašenosti vrši se poređenjem preporučenih uslova i načina održavanja od proizvođača, sa istim karakteristikama postojećeg sistema održavanja. Poređenjem se, prvenstveno, želi ustanoviti da li postoje veće razlike između:

- broja nivoa održavanja, snage,

- kvalifikacione strukture radne

- iskustva i uvežbanosti radne snage (npr. da li se predviđa da određene radnje vrše samo stalno zaposleni stručnjaci, odnosno profesionalci),

- dubine remontnog zahvata,

- uslova koji moraju vladati u prostoru u kojem se vrši održavanje (npr. minimalne varijacije temperature, zaštićenost od elektromagnetnih smetnji, da vazduh bude suv i bez prašine, da u njemu postoje kranovi, instalacija sa komprimovanim vazduhom $i$ slično).
Ako su ove razlike velike za nivoe osnovnog i trupnog održavanja koji se realizuju u jedinici korisnika, onda je najpogodnije odustati od nabavke takvog proizvoda. S druge strane, mogu se tolerisati manje razlike na nivou radioničkog i prilično velike neusklađenosti na nivou zavodskog održavanja (generalnog remonta).

Prilagođenost za korišćenje standardizovanih $i$ usvojenih vrsta goriva, maziva, municije ili izvora električne energije je sposobnost proizvoda da u svom radu isključivo (ili samo u slučaju nužde) koristi postojeće $i$ već ranije stvorene resiurse pogonskih sredstava i ostalih prethodno nabavljenih proizvoda. Treba istaći da se ovom prilagođenošću ne obezbeđuje veći stepen radne, nego borbene gotovosti nabavljenog proizvoda. Zbog toga se gorivo, municija i el «ktrična $€$ nergija obično zbirno nazivaju borbẹnim potrebama ili energijom boja.

Dokumentacija za održavanje obuhvata sva znanja i informacije koje treba da usvoje ili da se na njih podsete stručnjaci zaduženi za održavanje i remont. Pored štampanog materijala mogu je sačinjavati mikrofilmovi, video-filmovi, diskete i kompakt diskovi.

Individualni i grupni kompleti rezervnih delova, alata $i$ pribora (RAP) namenjeni su za osnovno održavanje sredstava, odnosno održavanje koje izvodi korisnik (rukovalac). Pri tome se rezervni delovi i potrošni materijal iz kompleta zamenjuju $u$ toku održavanja, dok se alatom, priborom (eventu.lno i zaštitnom opremom) realizuju ıadóvi održavanja.

Individualni komplet predviđa se za proizvode koji će se samo u jednom primerku dodeliti jedinici, a grupni komplet za sredstva koja će u istoj jedinici biti $u$ većem broju komada. 


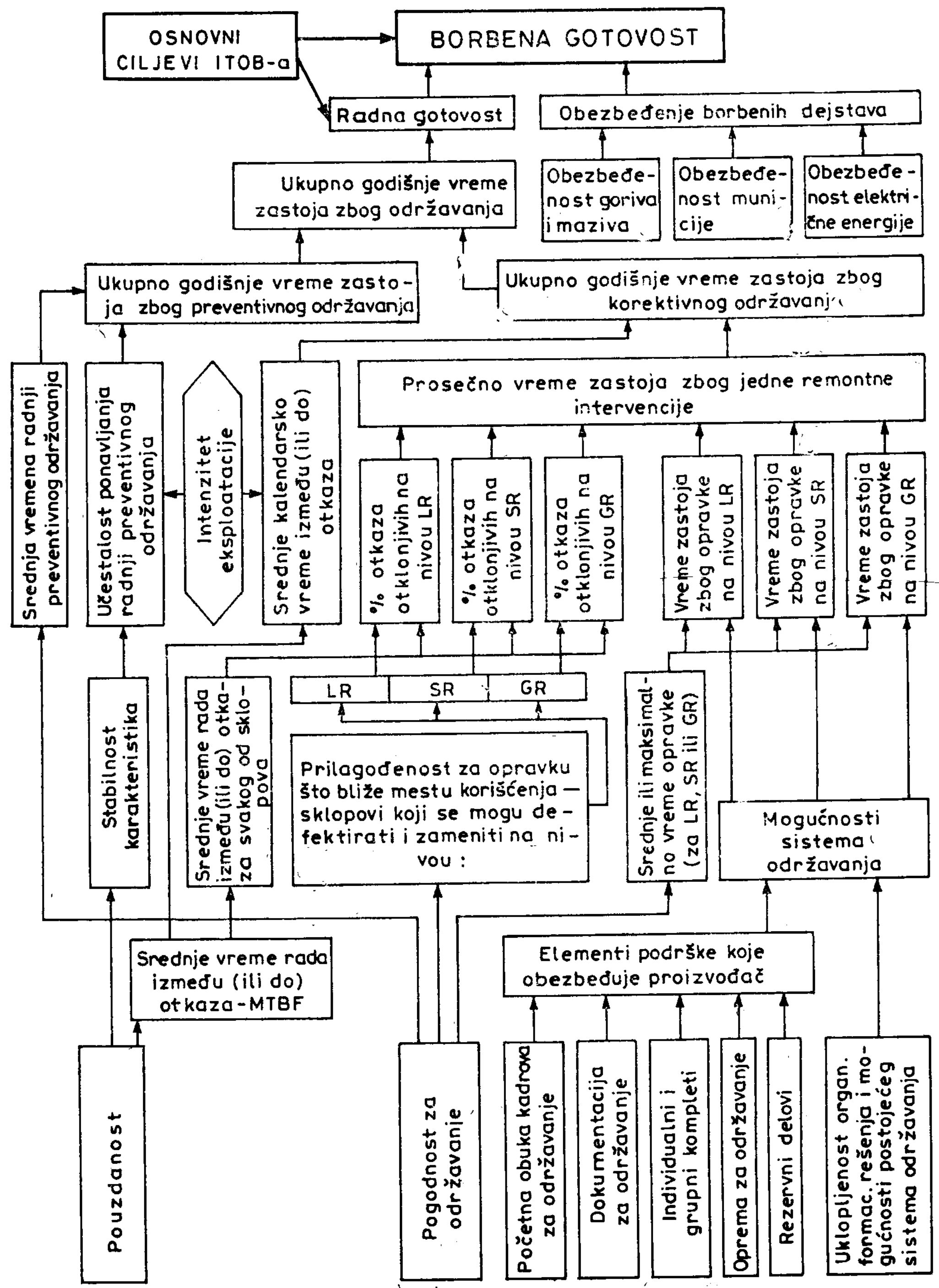

Povezanost elemenata ITOb-a 
Iako je osnovno održavanje problem eksploatacije (obavlja ga rukovalac ili posluga), ono sprečava pogoršanje pouzdanosti koje bi dovelo do povećanja broja otkaza sredstva. Zbog toga je za sistem održavanja veoma važno da li se i kako vrši osnovno održavanje proizvoda koje je nemoguće realizovati bez postojećeg individualnog ili grupnog kompleta RAP.

Oprema za održavanje $i$ ispitna oprema jeste skup svih nedostajućih opštih ili za konkretan proizvod namenski razvijenih alata, pribora, pomoćnih uređaja ili mernih sredstava, neophodnih za održavanje, manipulaciju i skladištenje.

Rezervni delovi su elementi, podsklopovi, sklopovi, delovi pribora i agregati potrebni za formiranje ratnih rezervi i mirnodopskih zaliha. Prilikom razmatranja ovog elementa ITOb-a ne ocenjuje se kvalitet delova (koji mora biti ocenjen $u$ okviru razmatranja kvaliteta ponuđenog proizvoda) nego utvrđuje sposobnost isporučioca da na pravilan način proračuna i predloži odgovarajuće ratne rezerve $\mathrm{i}$ mirnodopske zalihe (kako za popunu trupnog, tako i viših ešalona) i obezbedi odgovarajuće pakovanje i označavanje ovih delova. U okviru ovog razmatranja proverava se da li je ponuđač spreman i sposoban da garantuje i ostvari dugogodišnju isporuku rezervnih delova.

Početna obuka je proces prenošenja i usvajanja novih znanja i veština kojima se kadrovi, predviđeni za održavanje i remont određenog proizvoda, osposobljavaju za obavljanje ovog zadatka. Zahtevima u pogledu obuke prvenstveno se žele sagledati sposobnost $i$ opremljenost izvođača da kvalitetno i u okviru određenog vremena izvede sve potrebne vrste obuke.

Povoljan stepen radne $i$ borbene gotovosti ostvaruje se zadovoljenjem karakteristika elemenata ITOb-a, što je prikazano na slici.

Može se uočiti da su elementi ITOb-a polazna osnova za sagledavanje i proračun ukupnog godišnjeg vremena zastoja sredstva, zbog održavanja, iz kojeg se neposredno može sagledati ostvarivi stepen radne gotovosti.

Takođe, može se videti da se postizanje konačnog cilja (željenog stepena radne gotovosti) može ostvariti različitim kombinacijama vrednosti karakteristika elemenata ITOb-a, odnosno razumnim kompromisom vrednosti ovih karakteristika. Pri tome, treba naglasiti da ostvarenje željene radne gotovosti najviše zavisi od pouzdanosti, prilagođenosti za opravku što bliže mestu korišćenja, odnosno karakteristike pogodnosti za održavanje posebno značajne za radnu gotovost, od mogućnosti sistema održavanja i ostalih karakteristika pogodnosti za održavanje.

Prilikom donošenja odluke o nabavci nekog gotovog proizvoda prvenstvena pažnja treba da se usmeri na njegovu pouzdanost i prilagođenost za opravku što bliže mestu korišćenja. Prvu od ovih karakteristika morao bi deklarisati svaki solidniji proizvođač, a druga se može lako sagledati proučavanjem njegove remontne dokumentacije i pokušajem rada po ovoj dokumentaciji.

\section{Karakteristike integralnog tehničkog obezbeđenja}

Kadar uključen u problematiku razvoja ili nabavke sredstava ili sistema NVO uglavnom poznaje elemente ITOb-a, ali, samo mali broj stručnjaka je upoznat i sa karakteristikama ovih elemenata. Zbog toga su definisane najbitnije karakteristike i navedeni razlozi zbog kojih ih treba poznavati, ocenjivati i proveravati (tabela). 


\begin{tabular}{|c|c|c|c|c|c|c|}
\hline 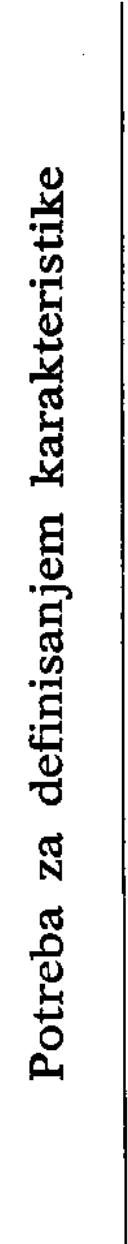 & + & 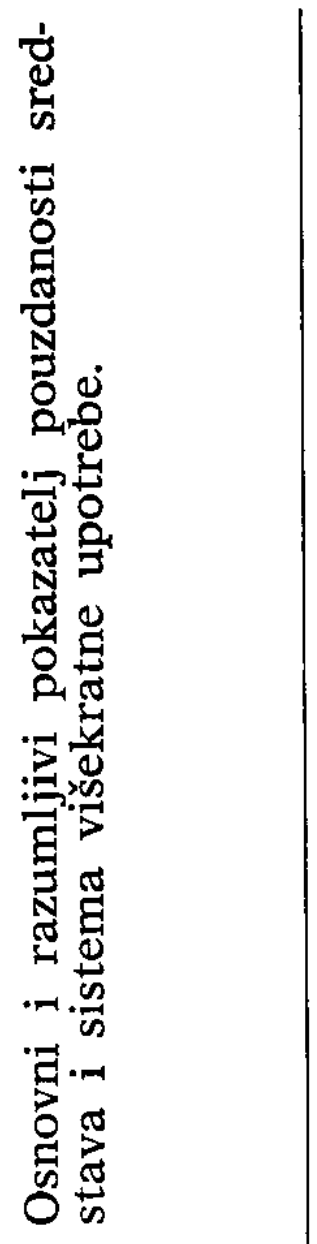 & 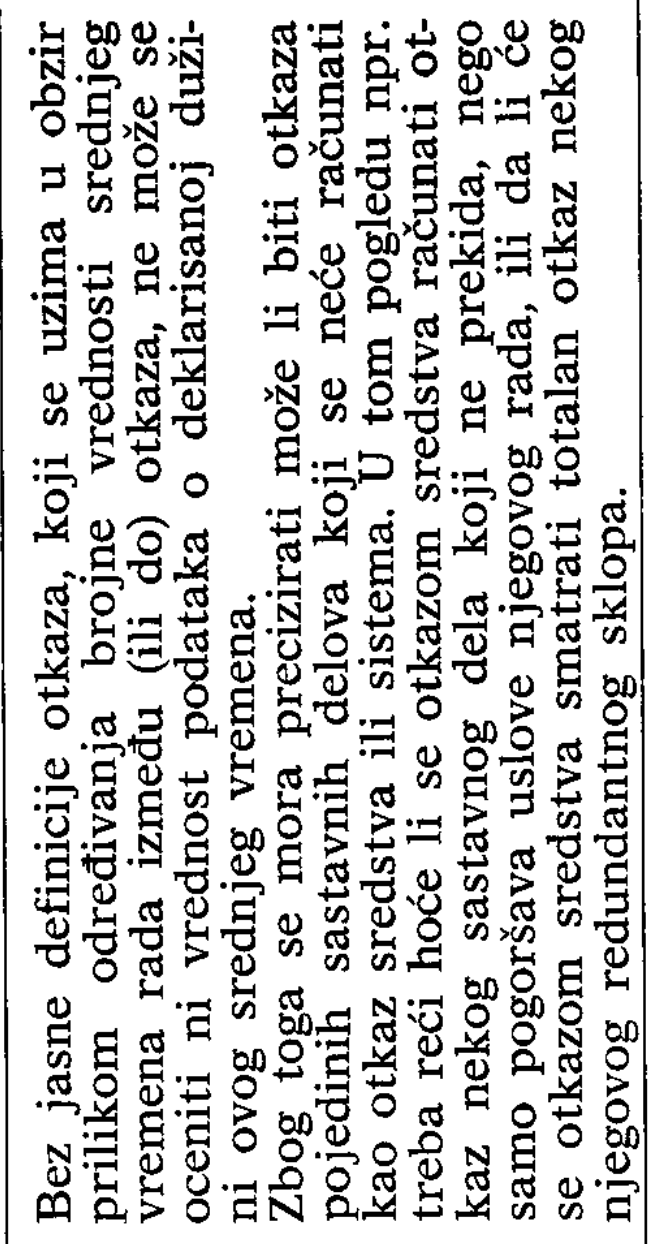 & 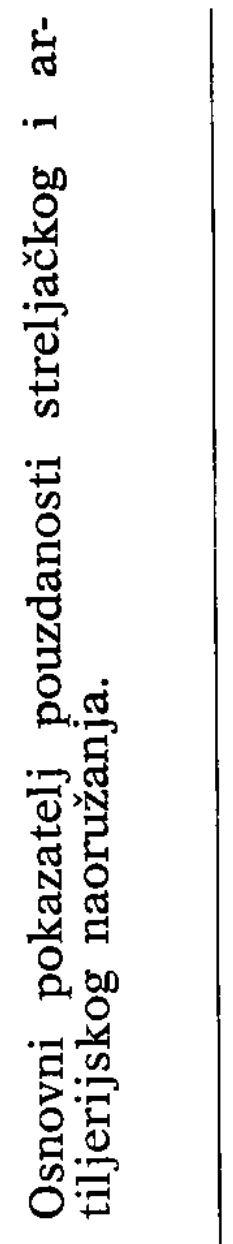 & 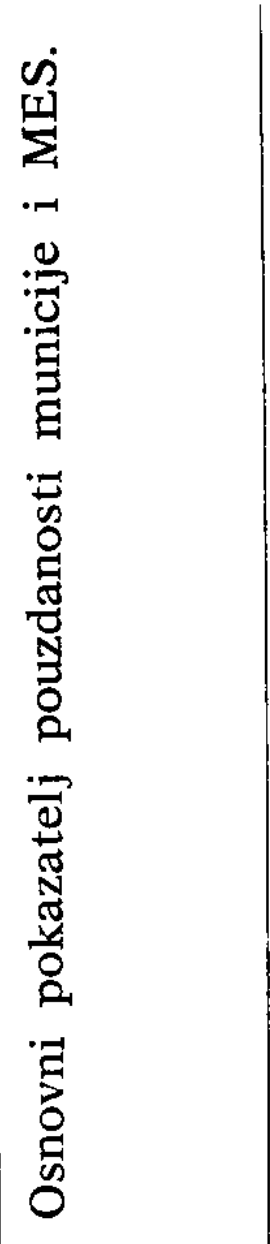 & 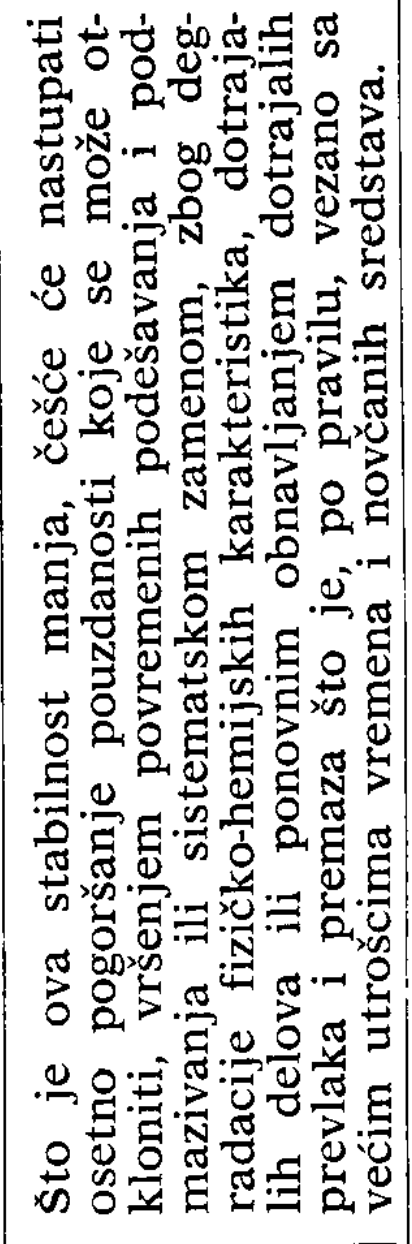 \\
\hline $\begin{array}{l}\text { 总 } \\
\text { 营 } \\
\text { ค̆ }\end{array}$ & $m$ & 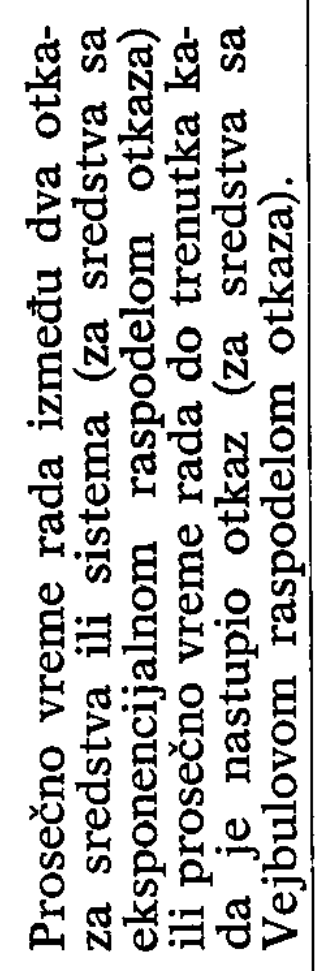 & 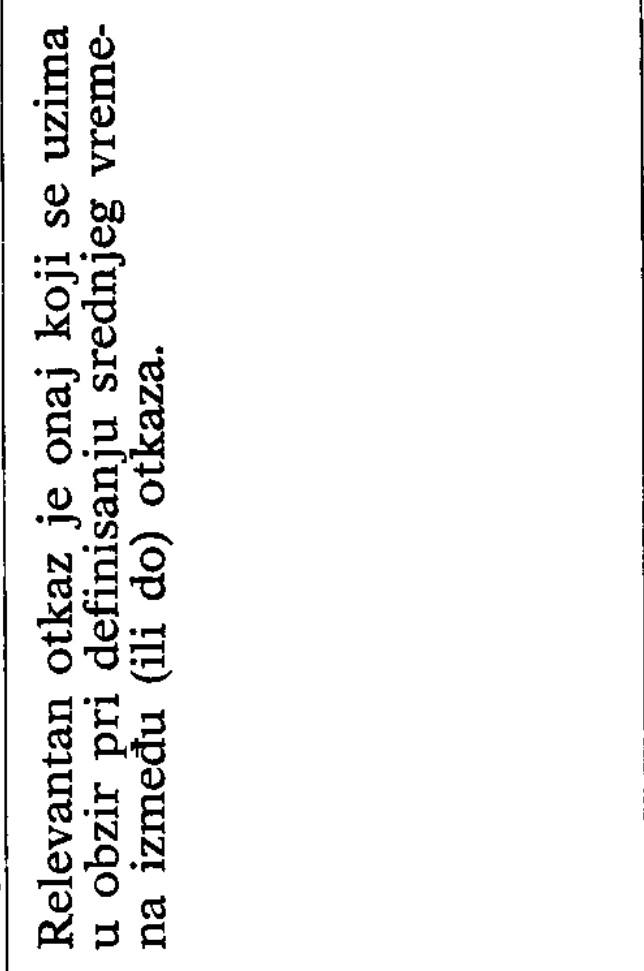 & 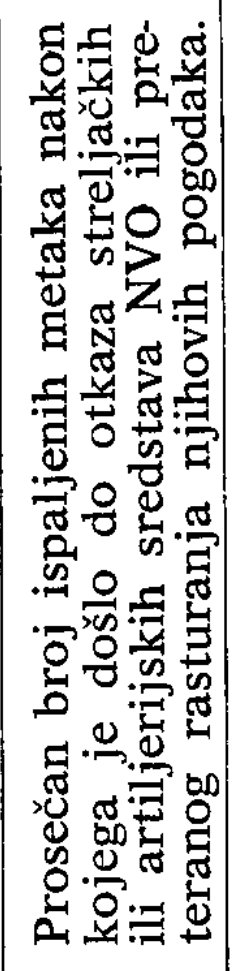 & 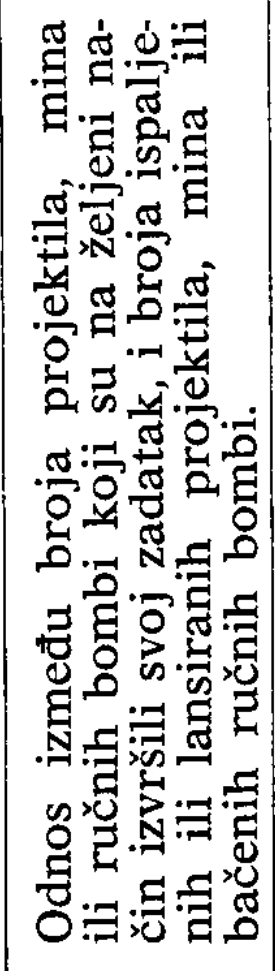 & 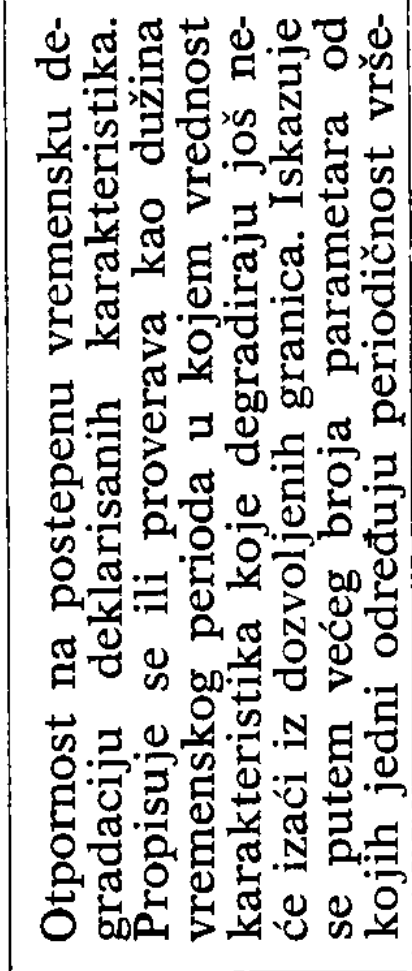 \\
\hline 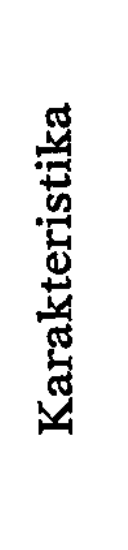 & $N$ & 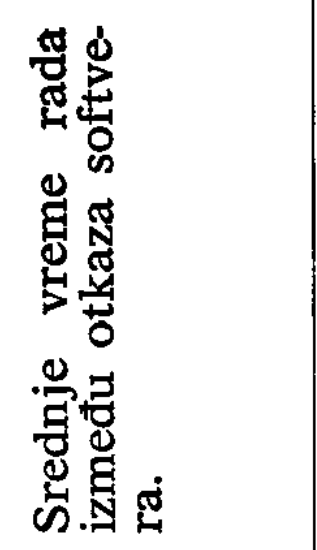 & 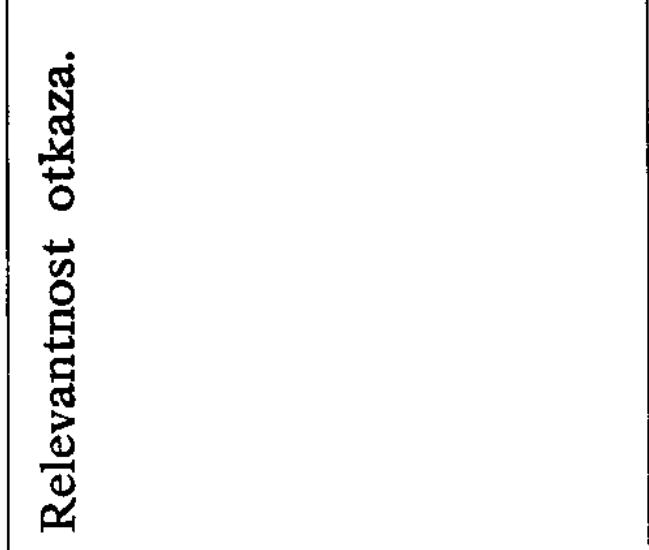 & 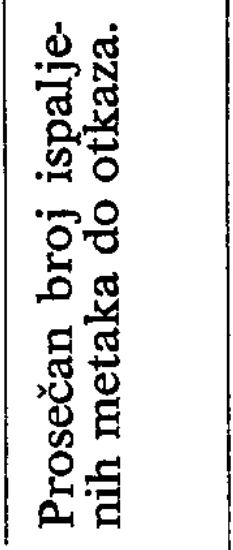 & 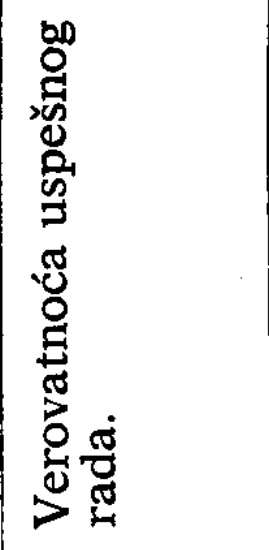 & 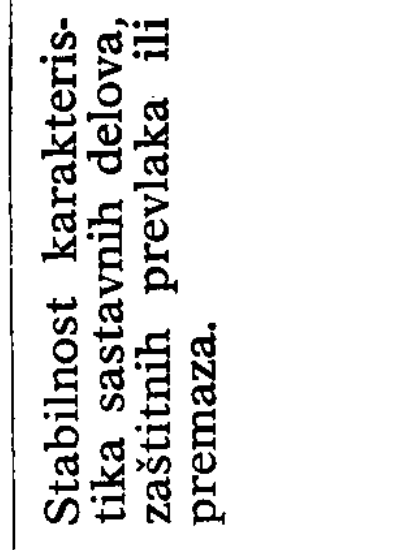 \\
\hline 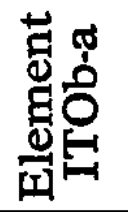 & - & \multicolumn{5}{|c|}{ fsourpzno d } \\
\hline
\end{tabular}




\begin{tabular}{|c|c|c|c|c|c|c|}
\hline$T$ & & 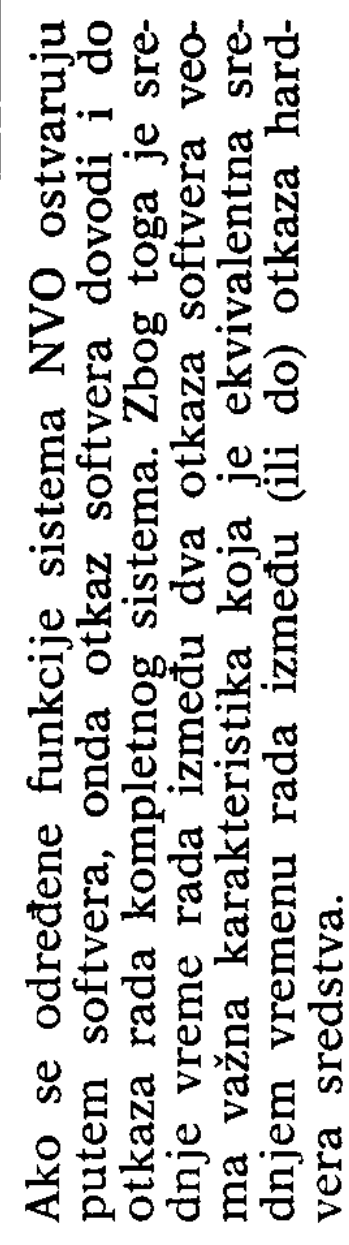 & 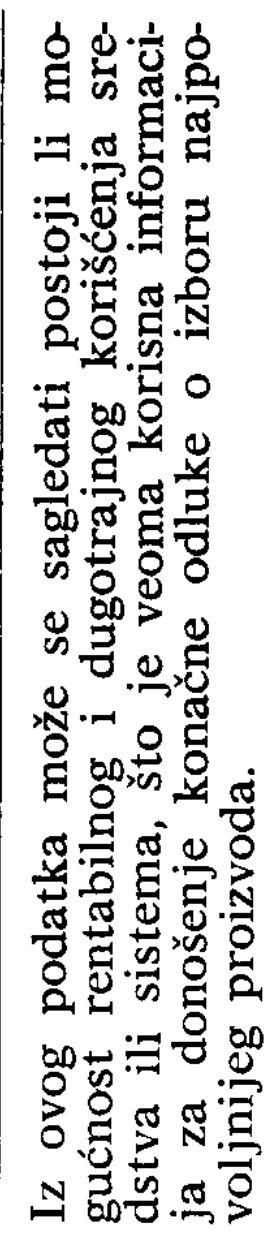 & 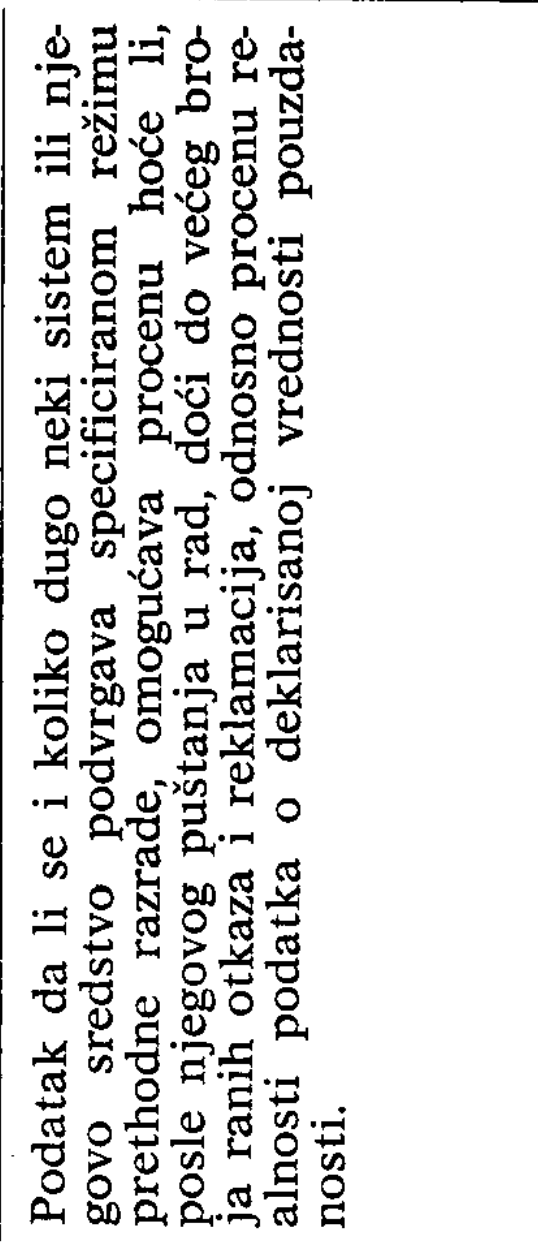 & \multicolumn{2}{|c|}{ 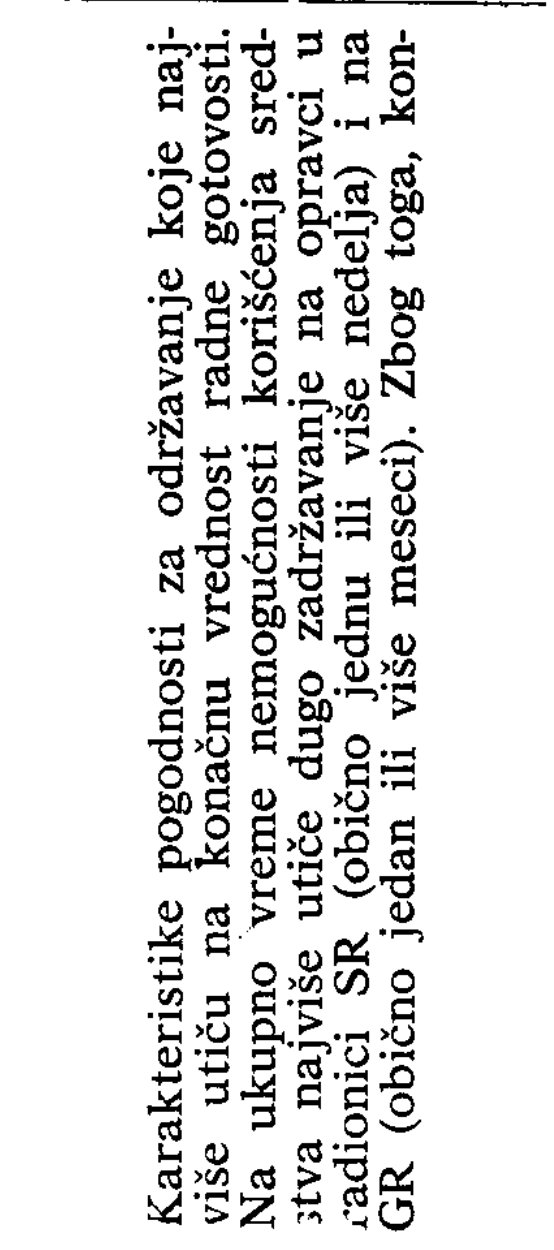 } \\
\hline$m$ & 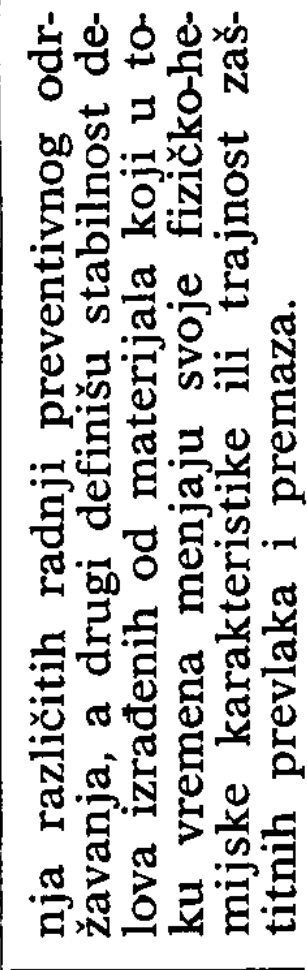 & 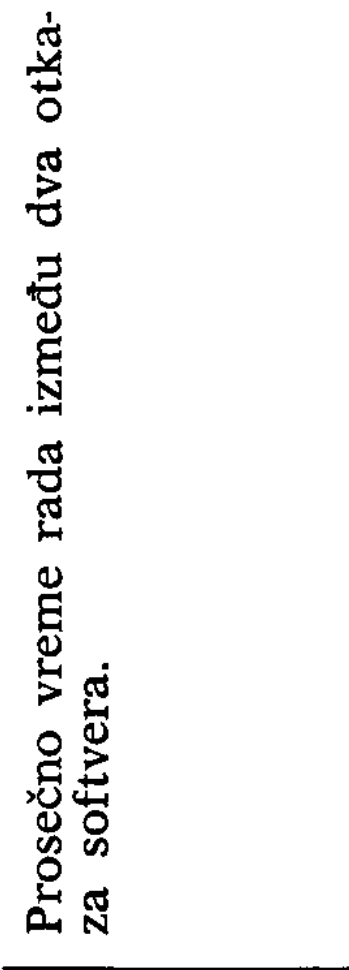 & 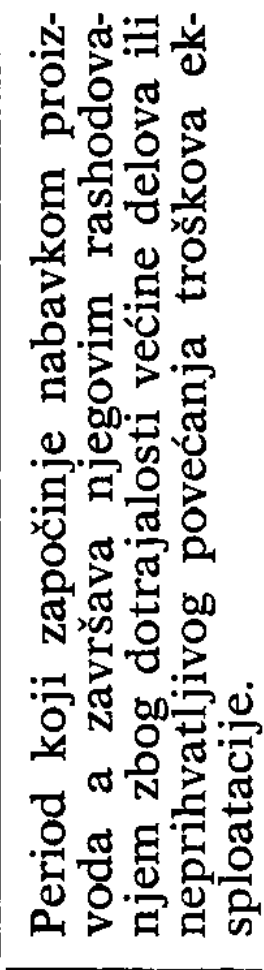 & 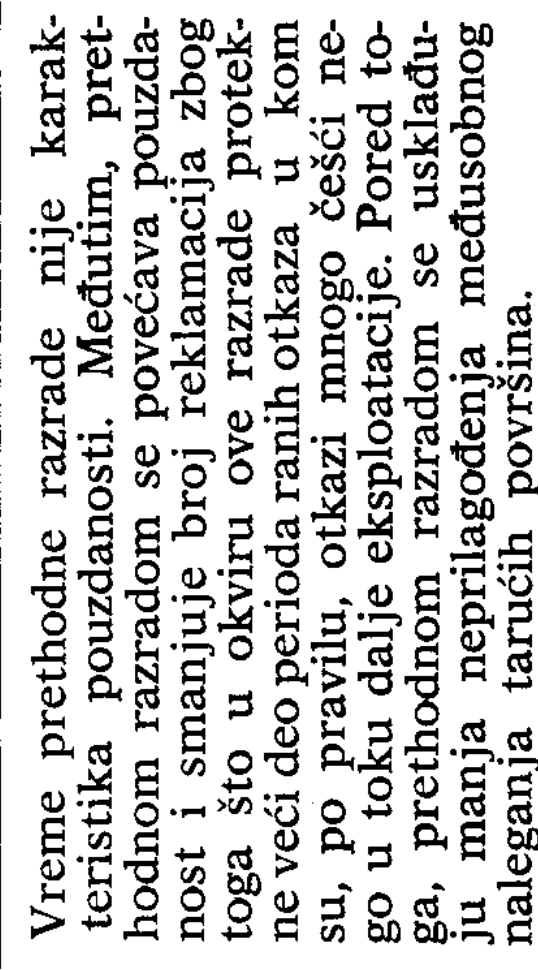 & 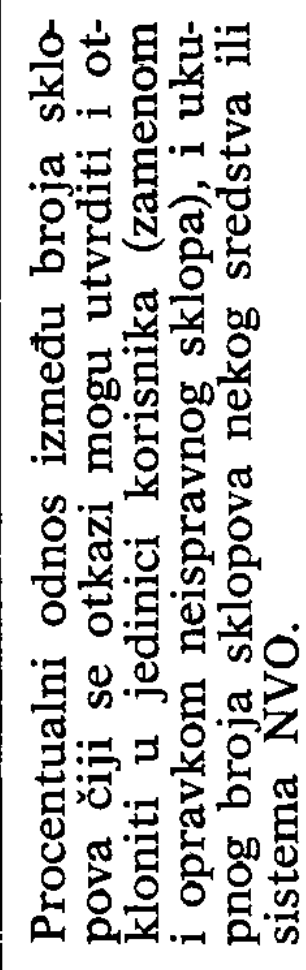 & 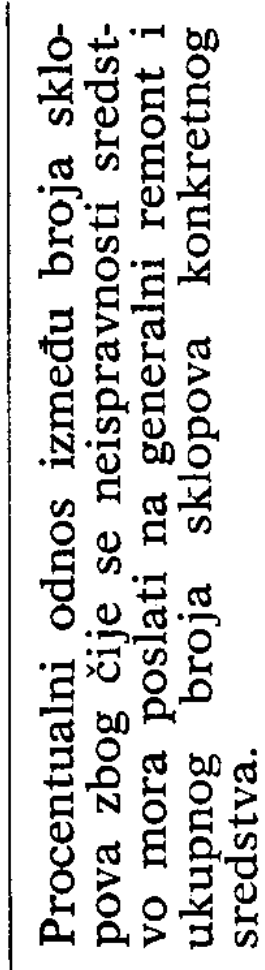 \\
\hline$N$ & & 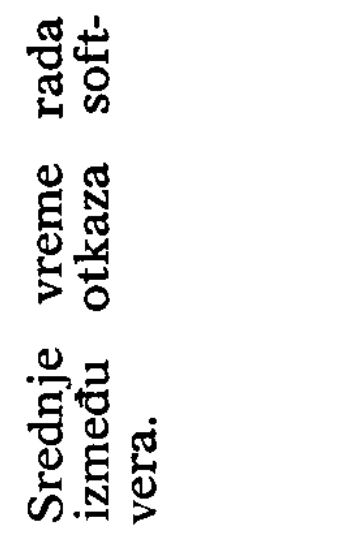 & 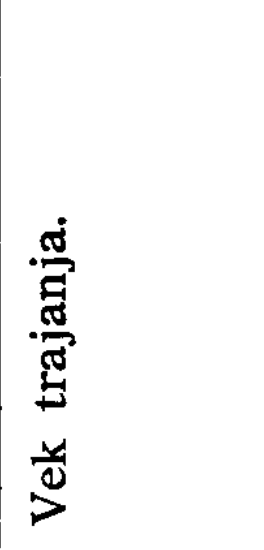 & 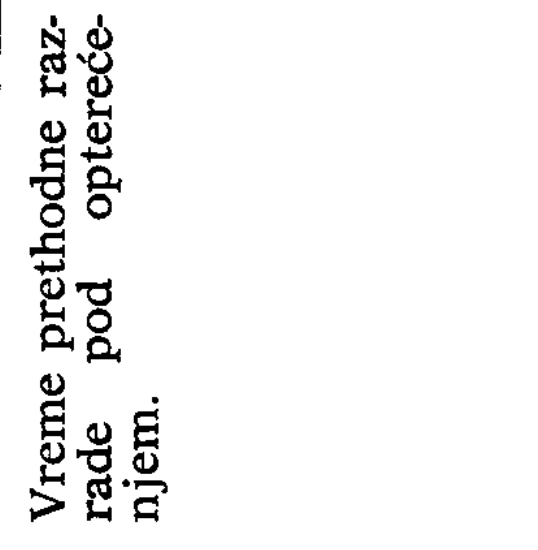 & 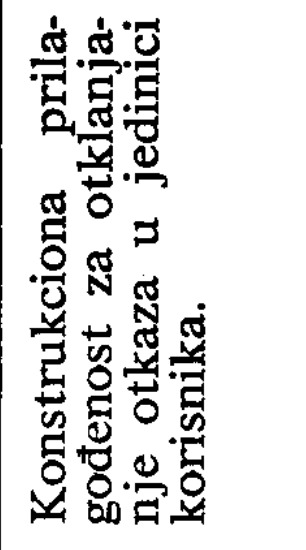 & 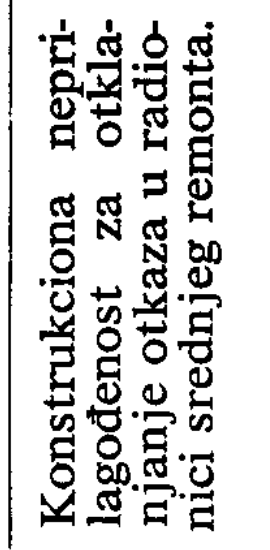 \\
\hline r & & & Jurpznod & & $\mathrm{ez} 7 \mathrm{~s}$ & poŝ̀o \\
\hline
\end{tabular}




\begin{tabular}{|c|c|c|c|c|}
\hline$\nabla$ & 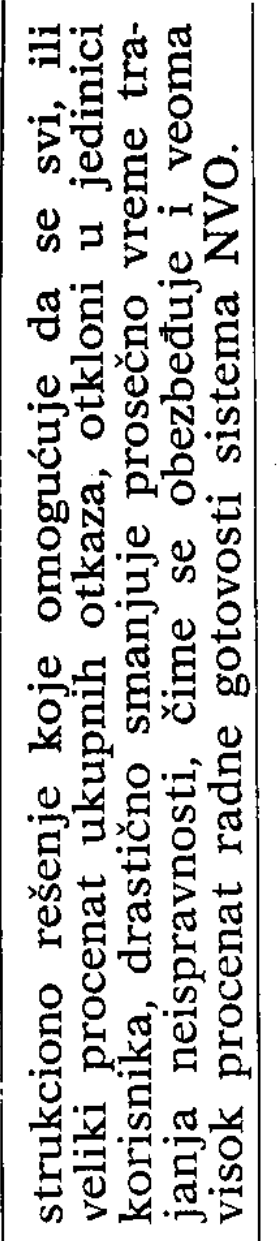 & 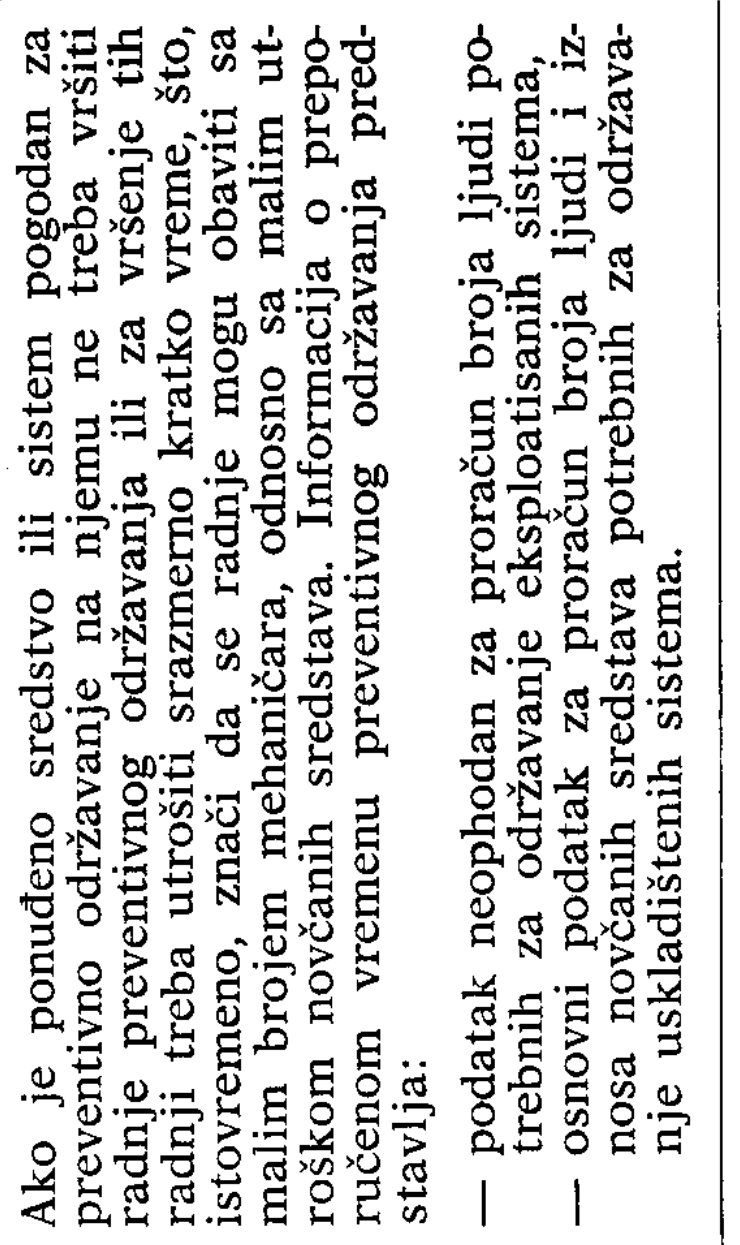 & 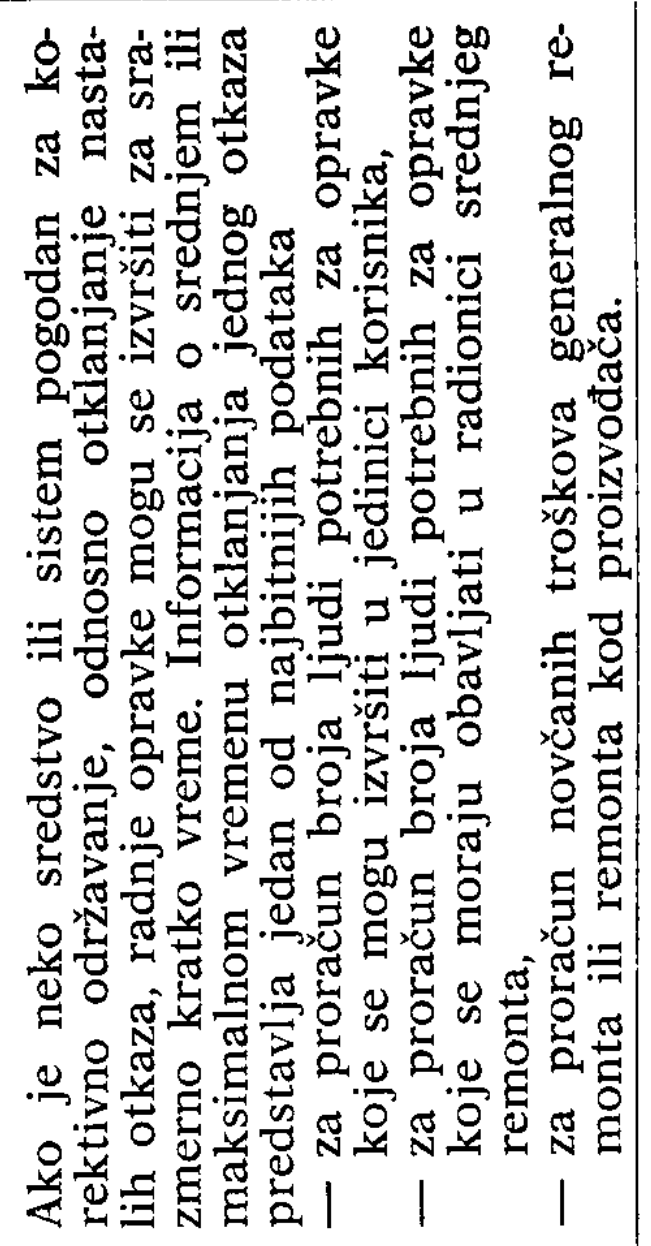 & 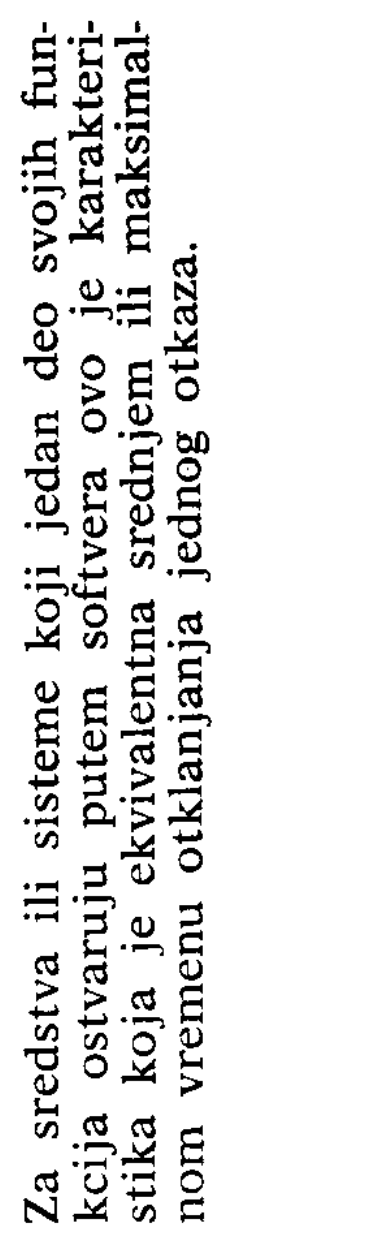 \\
\hline$m$ & 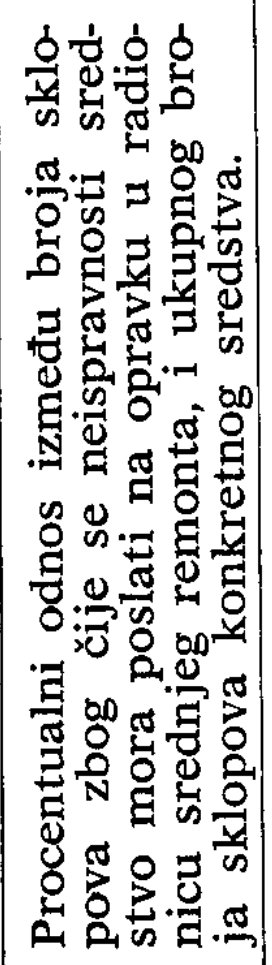 & 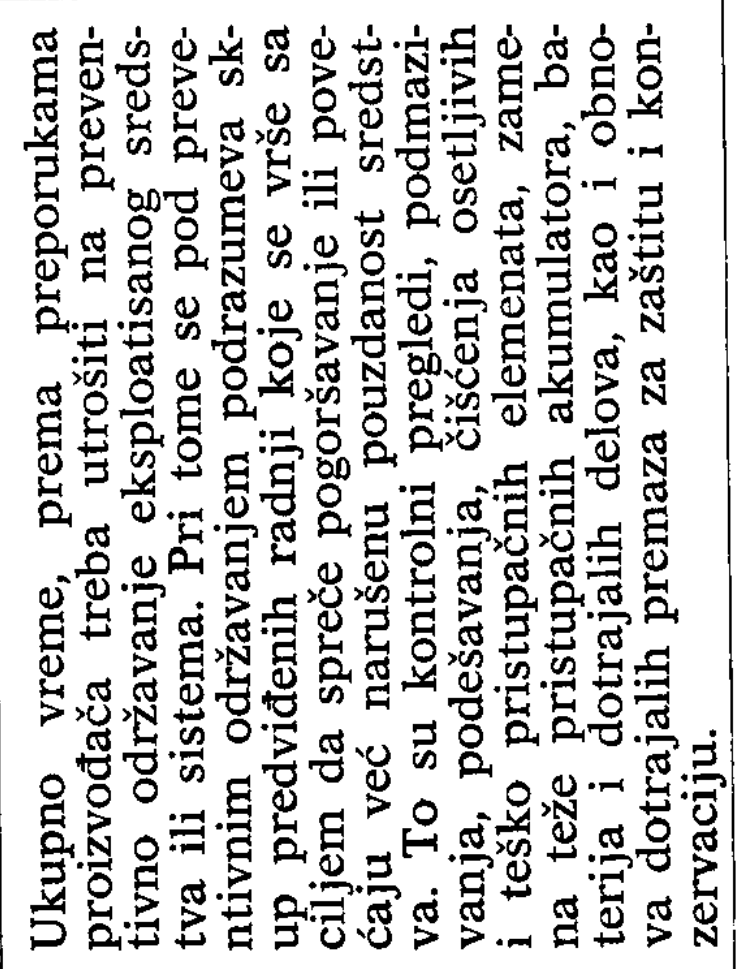 & 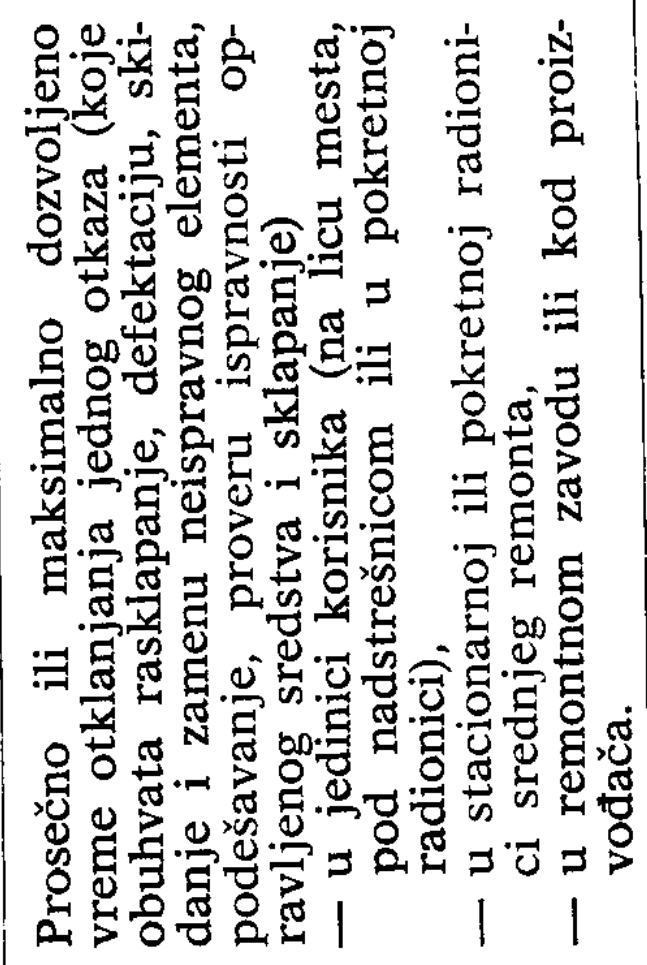 & 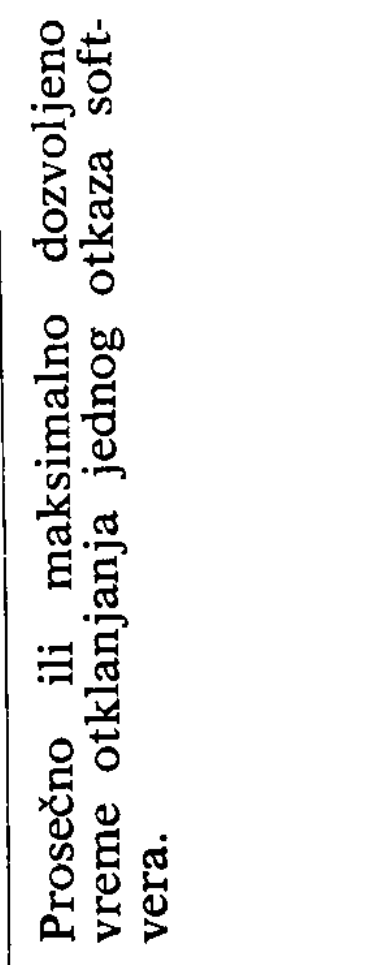 \\
\hline$N$ & 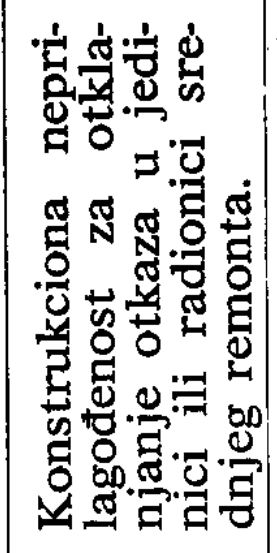 & 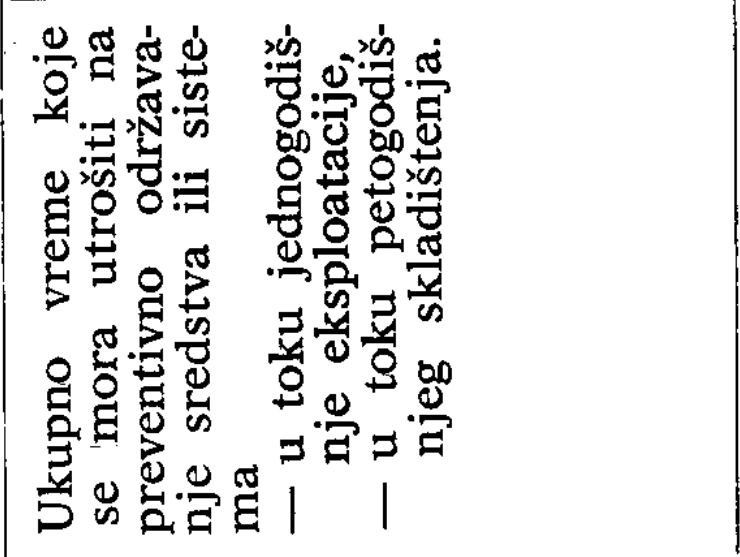 & 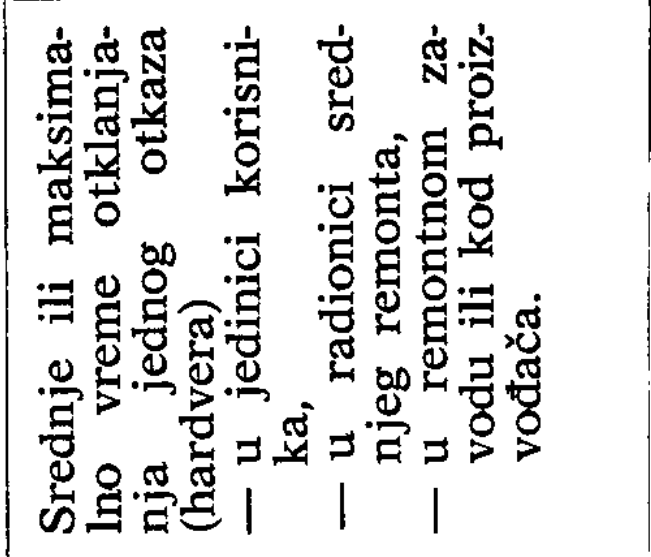 & 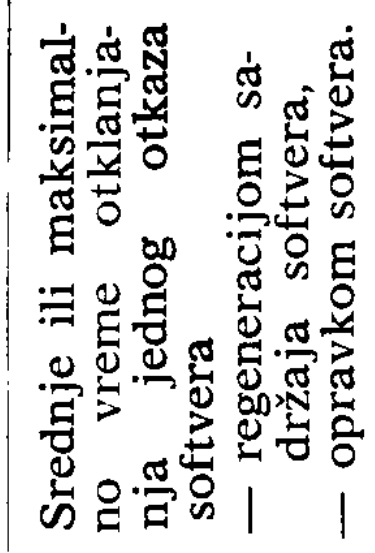 \\
\hline-1 & \multicolumn{4}{|c|}{ 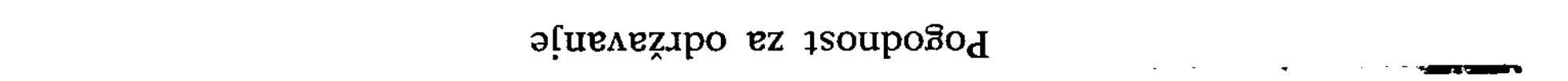 } \\
\hline
\end{tabular}




\begin{tabular}{|c|c|c|c|c|c|c|c|}
\hline$\nabla$ & 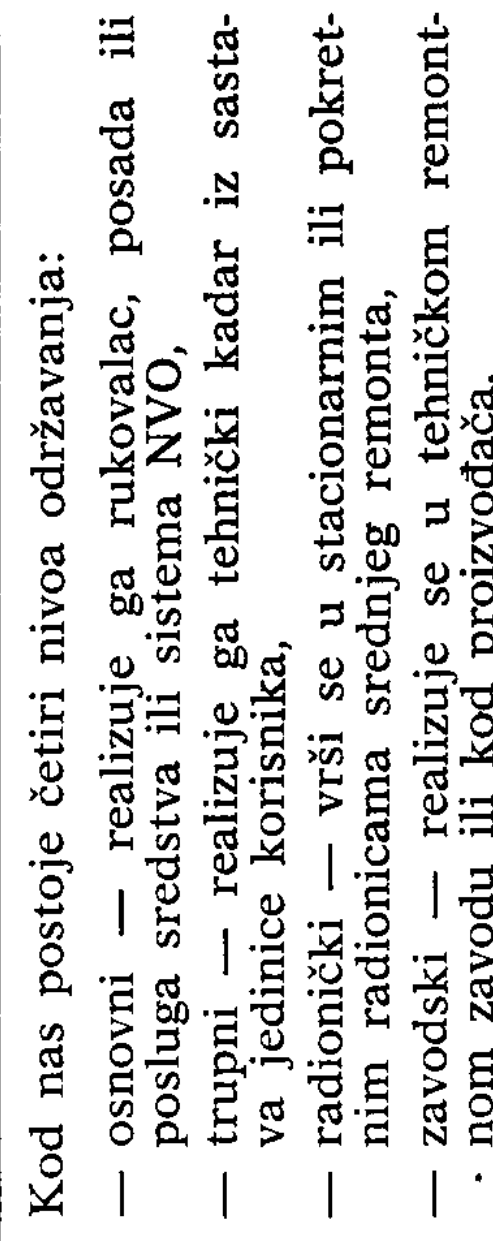 & 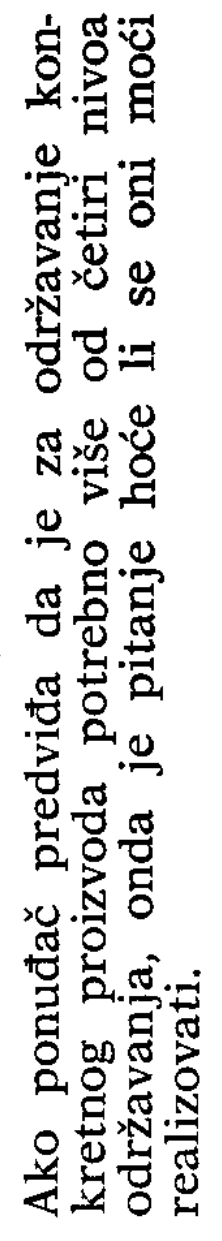 & 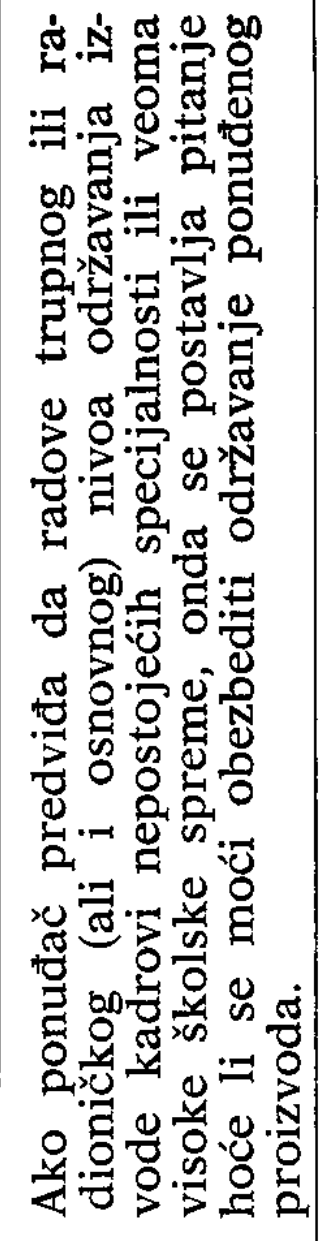 & 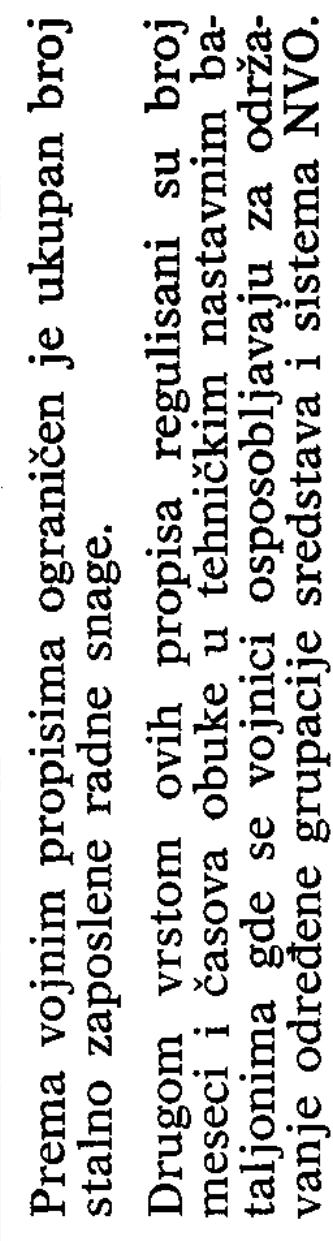 & 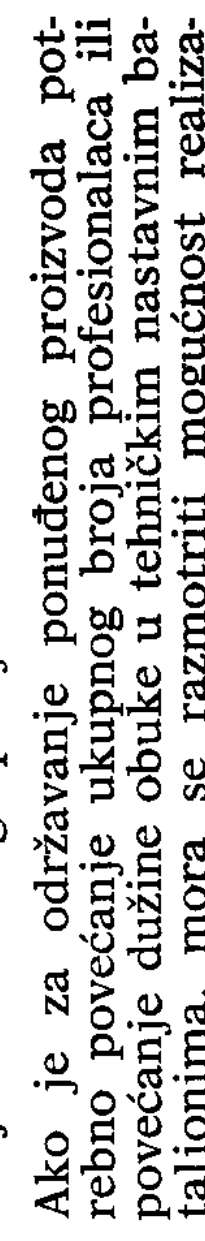 & 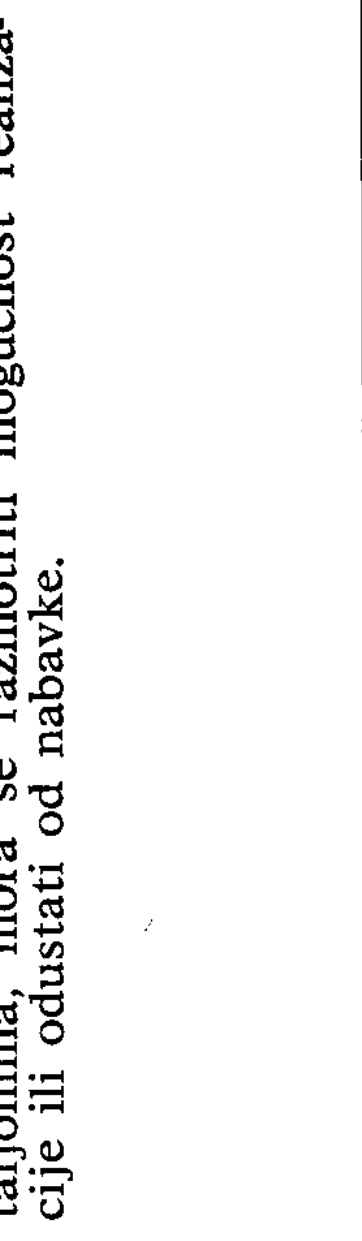 & 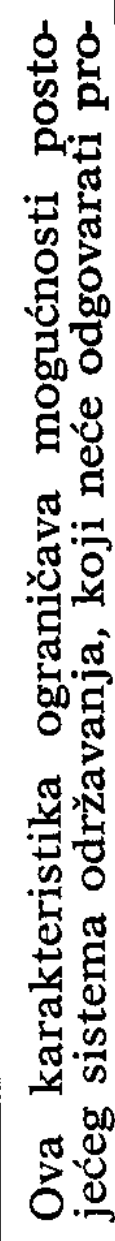 \\
\hline$m$ & 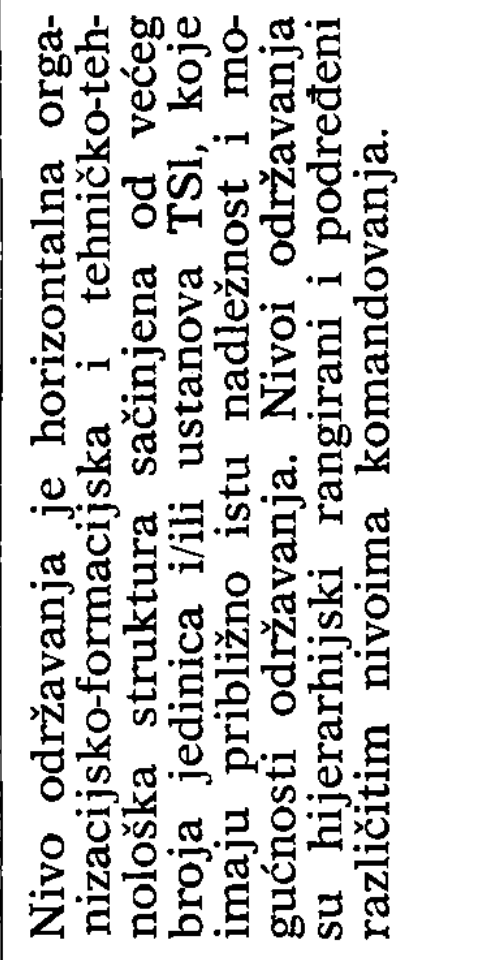 & & 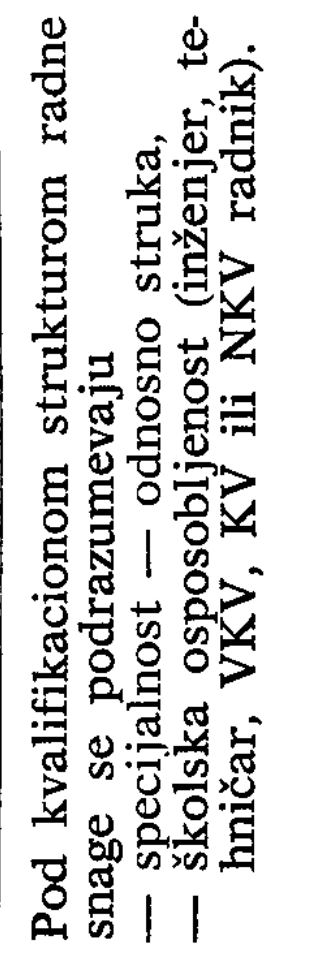 & 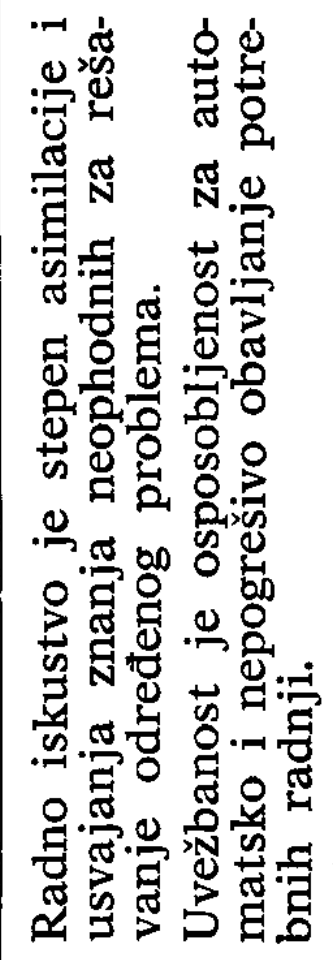 & 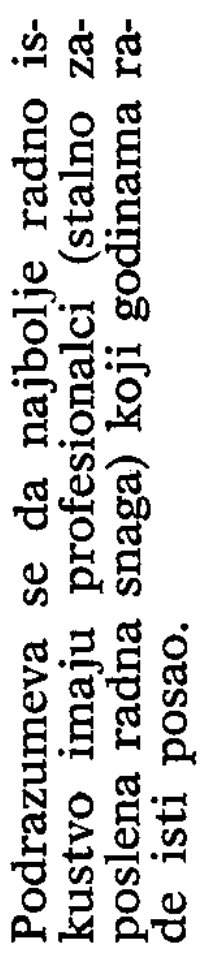 & 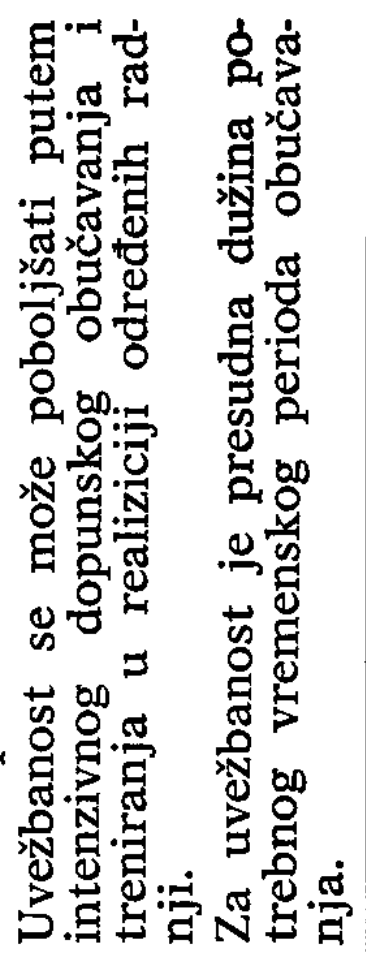 & 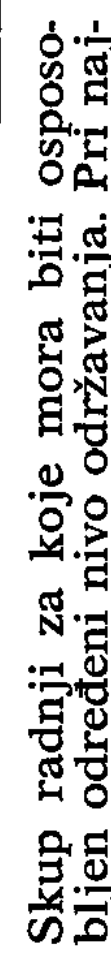 \\
\hline $\mathbf{N}$ & 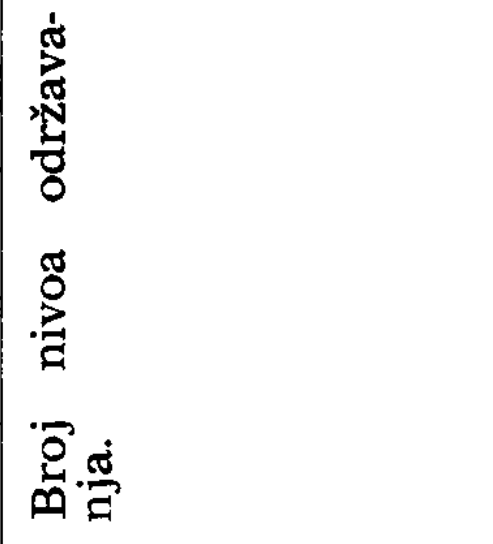 & & 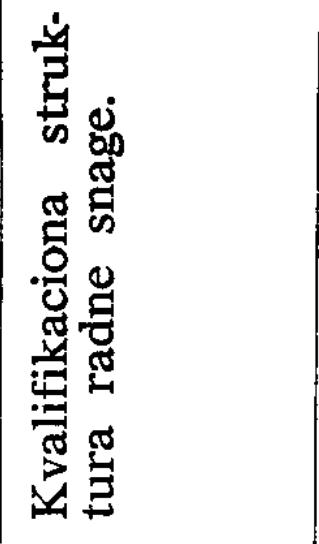 & 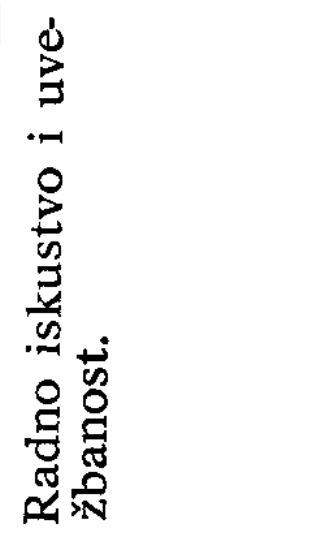 & & & 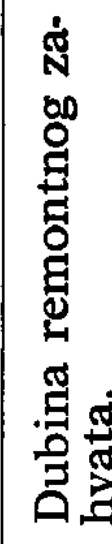 \\
\hline$\varpi$ & & 19 & 0 & $\begin{array}{l}\text { ez!̣ues.jo n } \\
\text { spass } 7 \text { sou }\end{array}$ & $\overline{o p}[\mathrm{IL}$ & & \\
\hline
\end{tabular}




\begin{tabular}{|c|c|c|c|c|c|}
\hline$\theta$ & 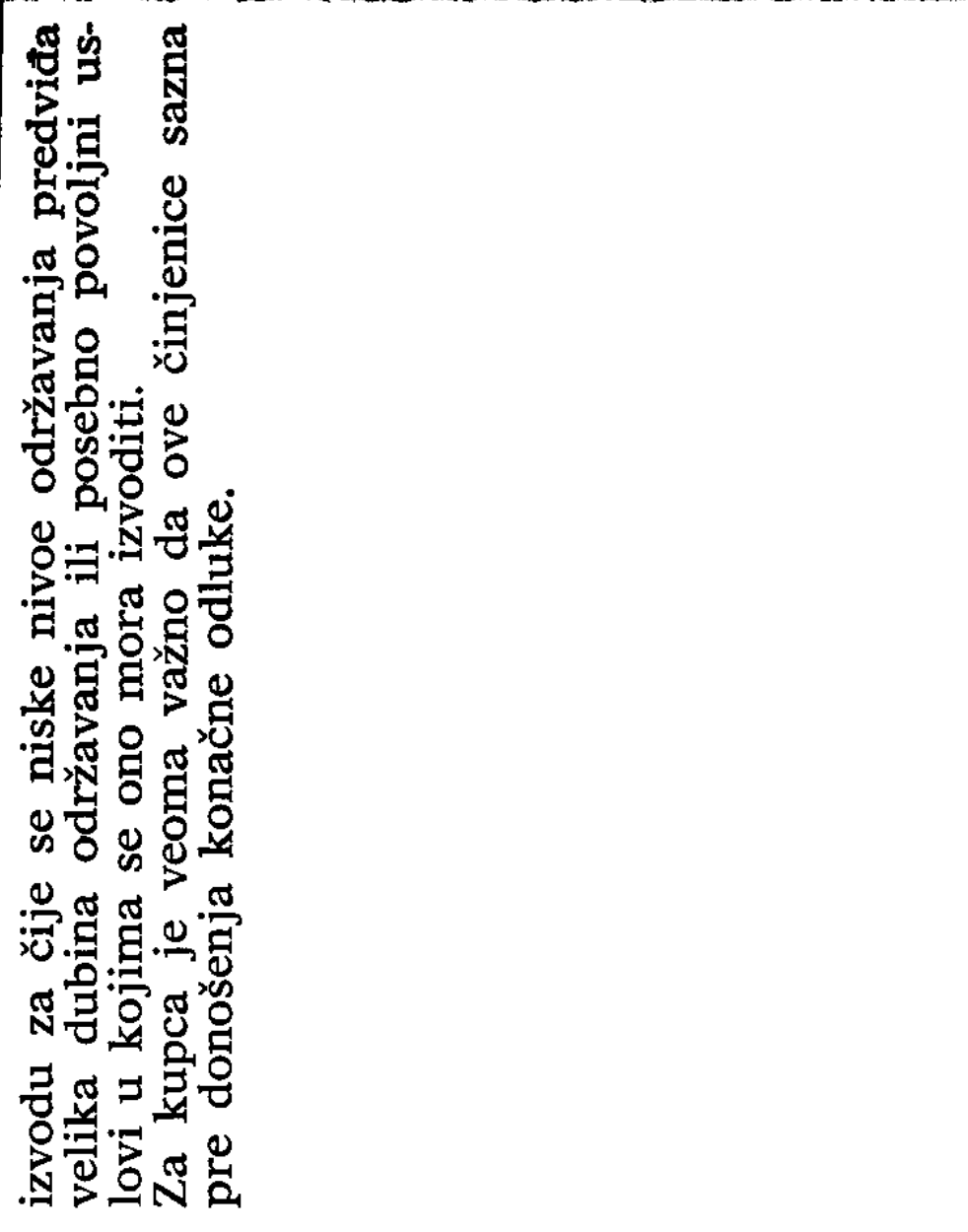 & & 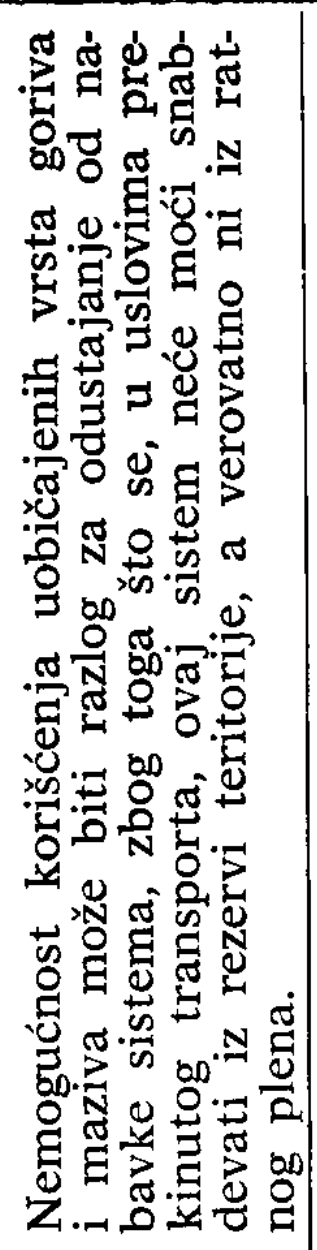 & 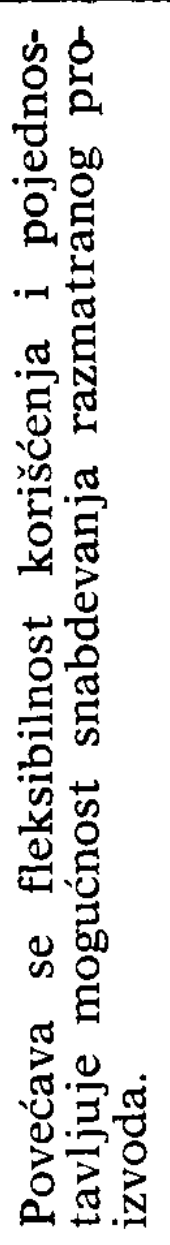 & \\
\hline$m$ & 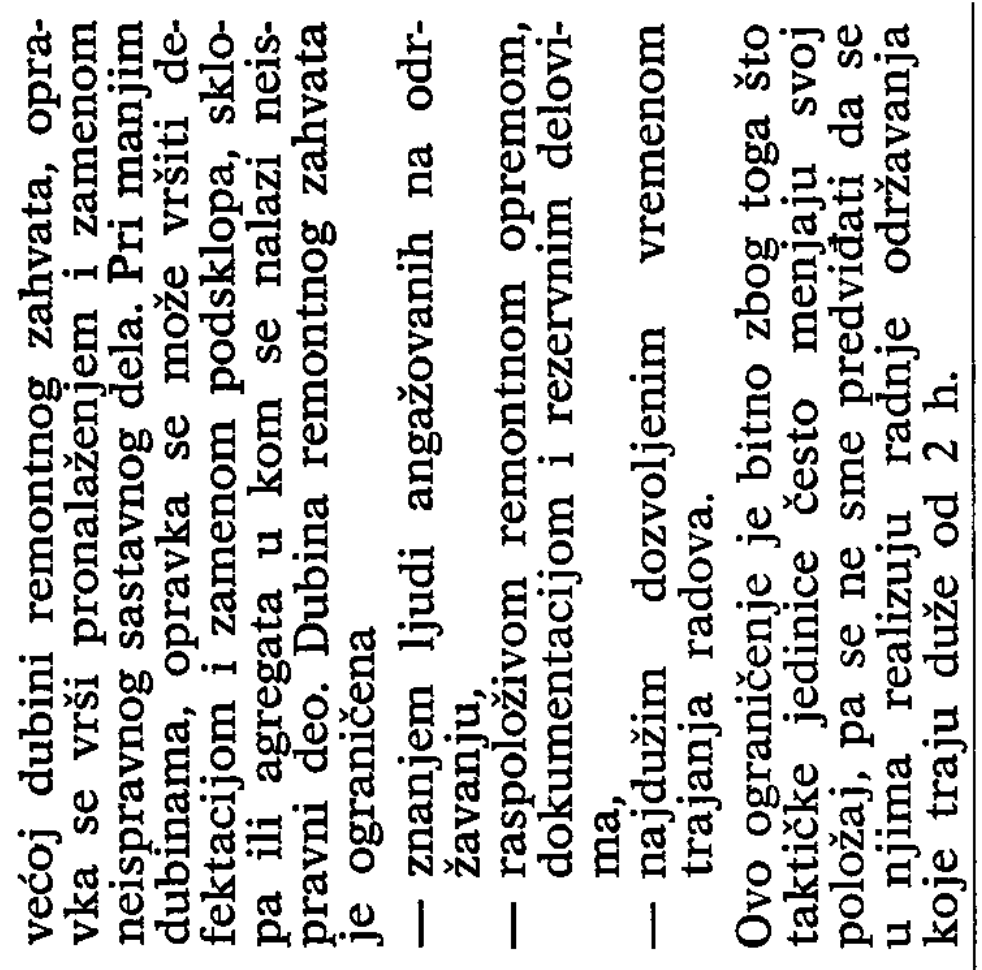 & 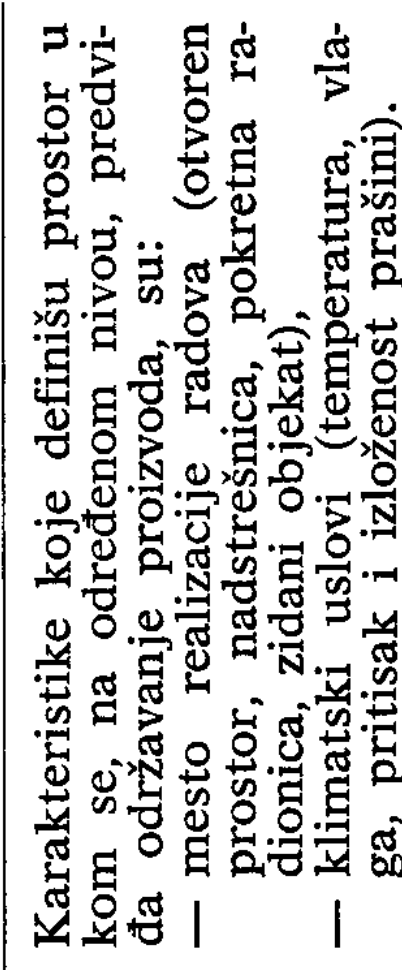 & 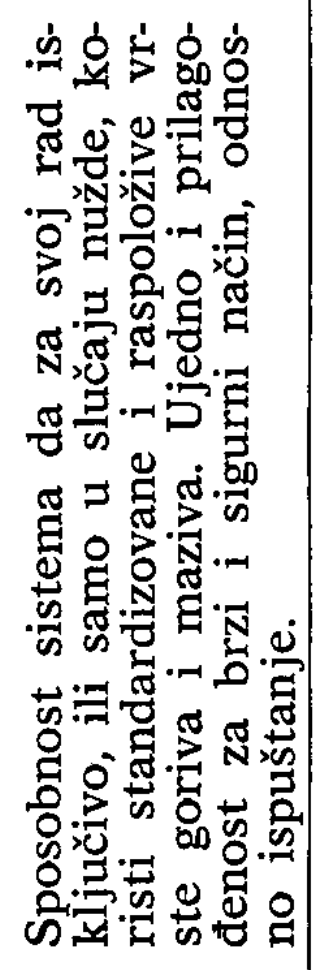 & 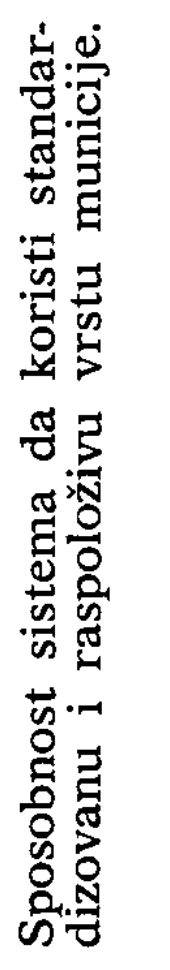 & 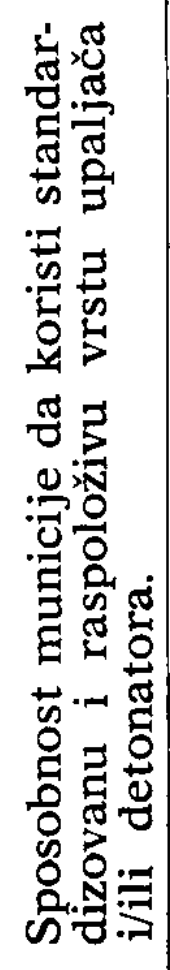 \\
\hline$N$ & & 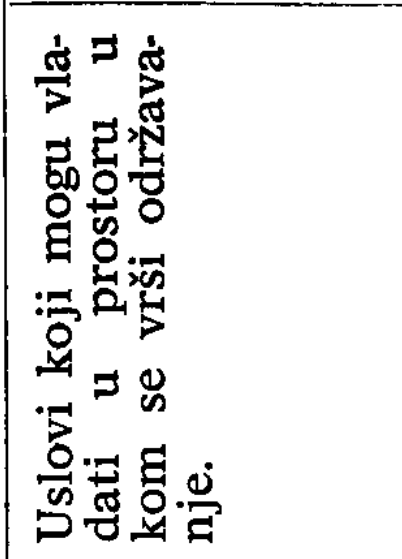 & 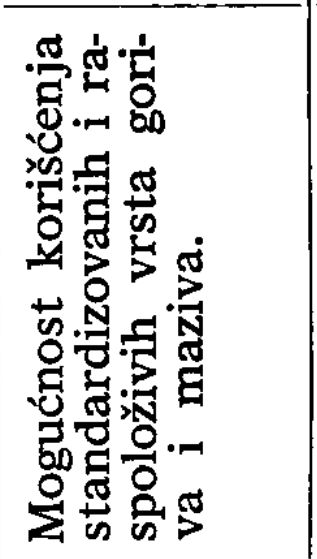 & 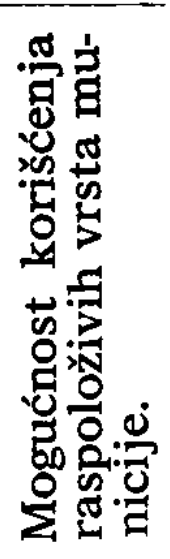 & 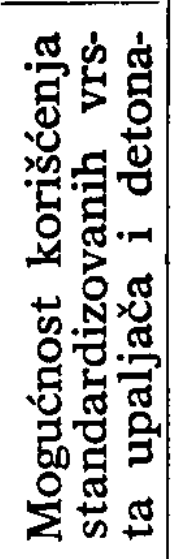 \\
\hline-1 & \multicolumn{2}{|c|}{ 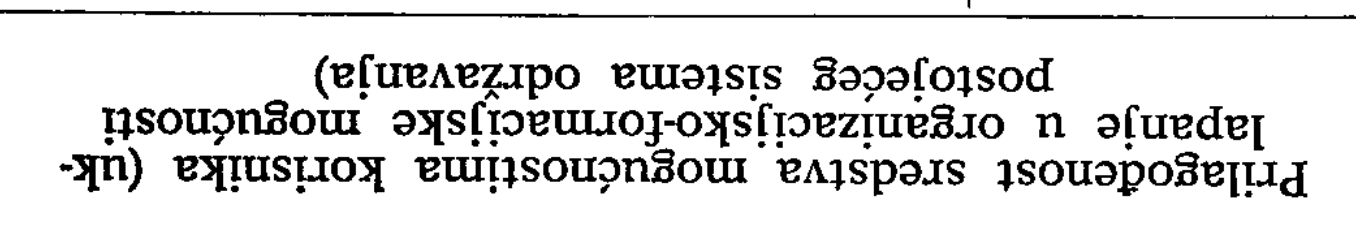 } & 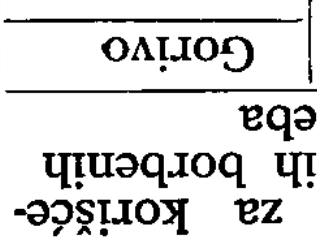 & $\mathbb{R}$ [!? & 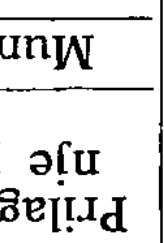 \\
\hline
\end{tabular}




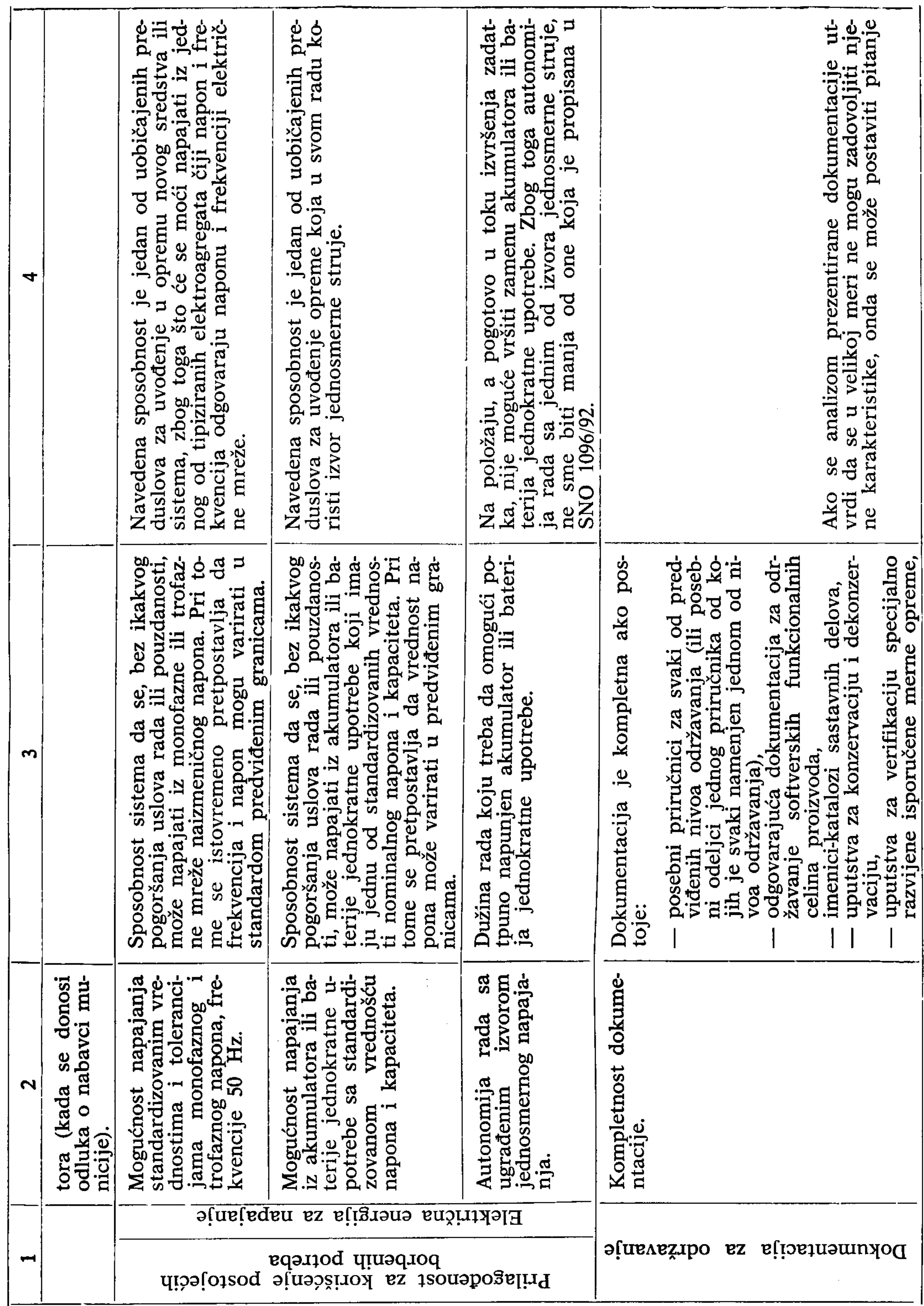




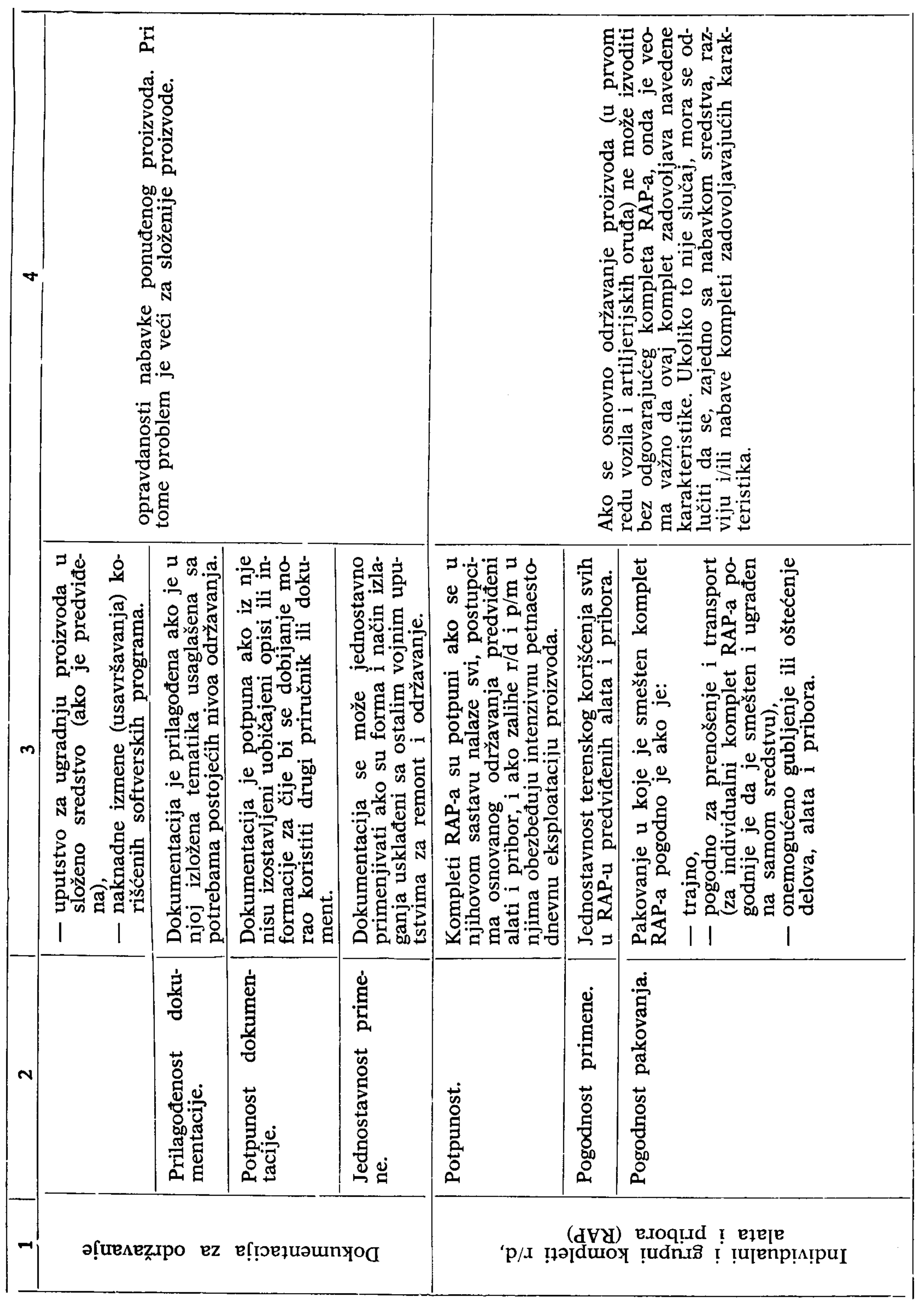




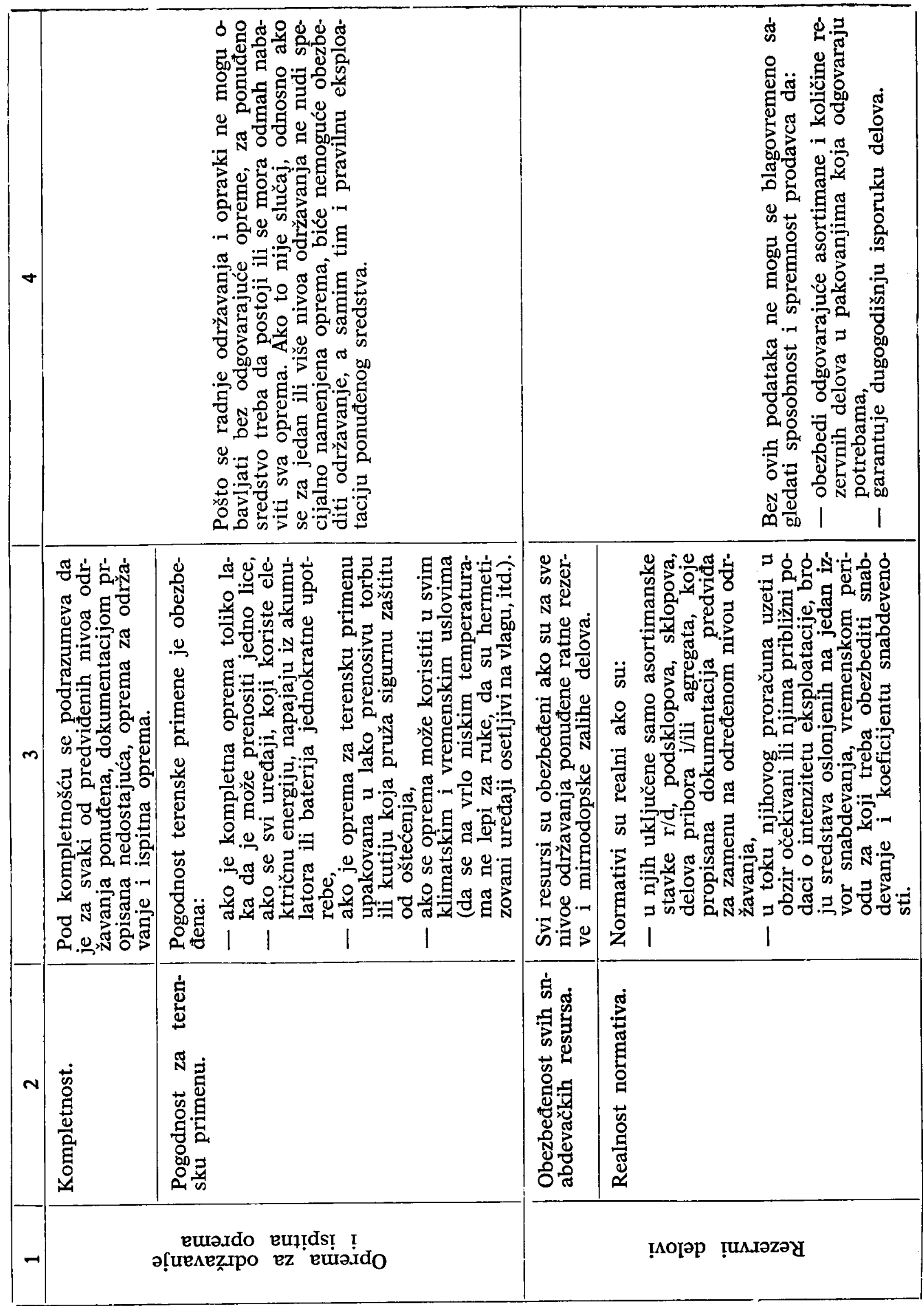




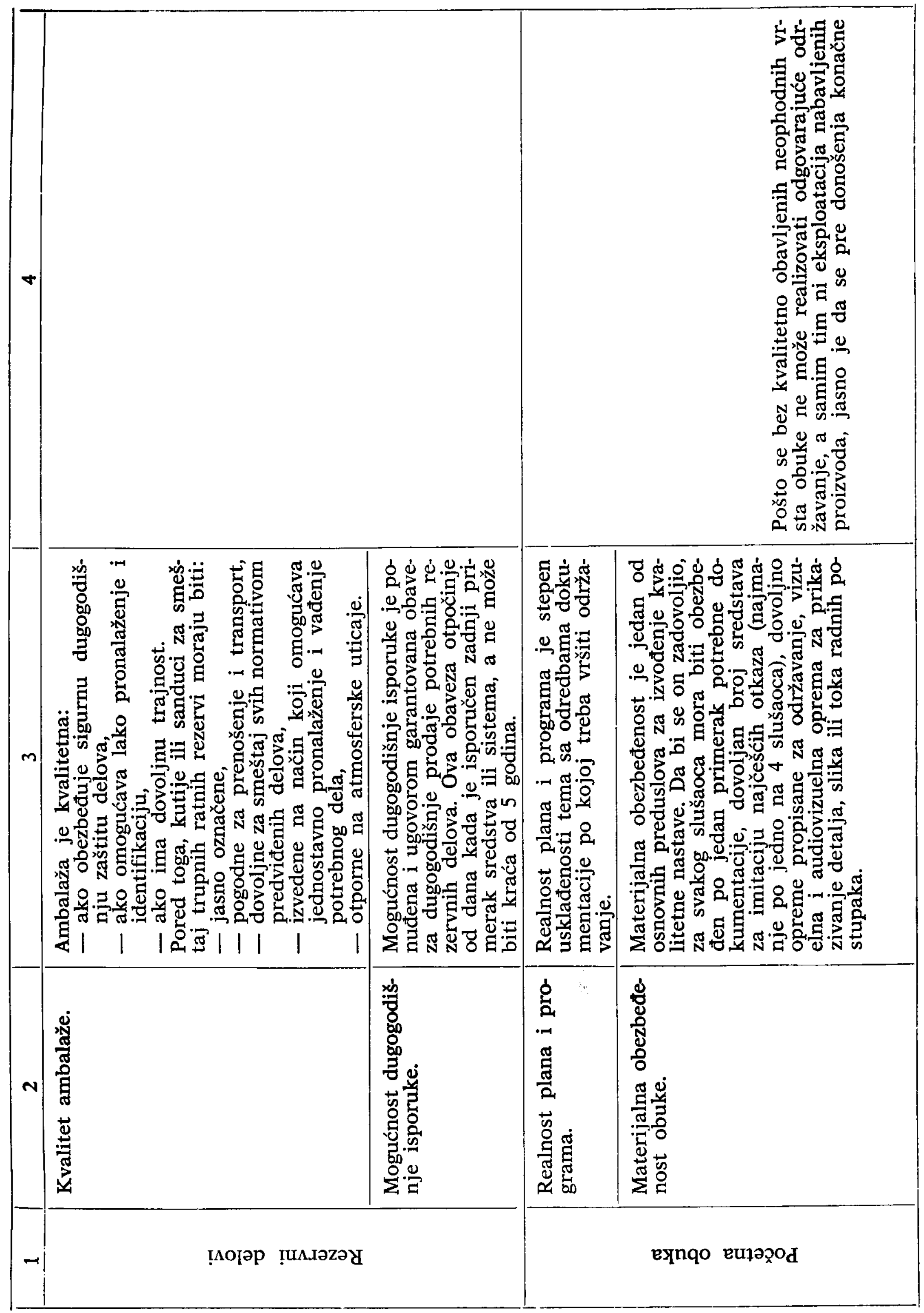




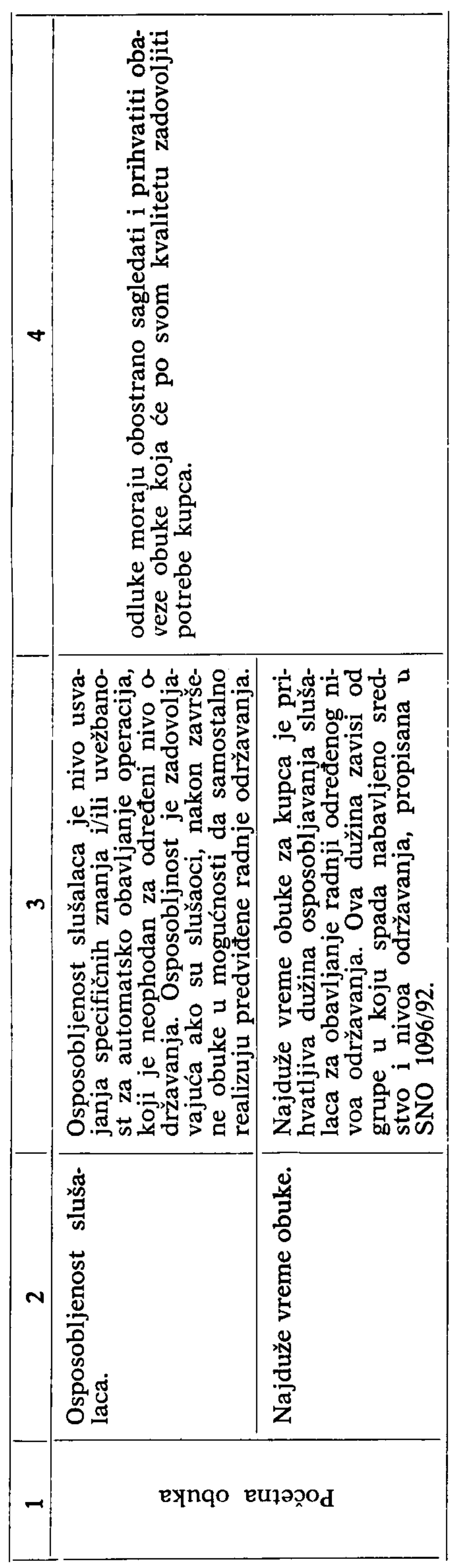




\section{Zaključak}

U ovom radu navedene su najvažnije karakteristike ITOb-a koje su detaljno razrađene $i$ precizirane $u$ SNO 1096 Taktičko-tehnički zahtevi za sredstva i sisteme NVO. Za korisnika je značajno da pre početka ugovaranja razvoja ili pre donošenja odluke o nabavci propiše i proveri vrednost svih karakteristika. Ako se to ne učini, ne može se očekivati da će razvijeno ili nabavljeno sredstvo ili sistem NVO imati željeni stepen radne gotovosti niti se mogu sagledati problemi koje će izazvati uvođenje ovakvog proizvoda $u$ naoružanje i vojnu opremu. Blagovremeno propisivanje i provera vrednosti navedenih karakteristika znatno smanjuje rizik donošenja pogrešne odluke i istovremeno pruža mogućnost da se pre nabavke ili proizvodnje konkretnog sredstva sagledaju sve poteškoće, i utvrdi da li će njegovo uvođenje $u$ NVO zahtevati određene organizacijsko-formacijske promene. Time se obezbeđuje dovoljno vremena da se pre početka korišćenja sredstva završe sve neophodne pripreme ili promene, što će umanjiti probleme početne eksploatacije i održavanja. 